\title{
Testate Amoeba Functional Traits and Their Use in Paleoecology
}

\author{
Katarzyna Marcisz ${ }^{*}$, Vincent E. J. Jassey², Anush Kosakyan ${ }^{3}$, Valentyna Krashevska ${ }^{4}$, \\ Daniel J. G. Lahr ${ }^{5}$, Enrique Lara ${ }^{6}$, Łukasz Lamentowicz ${ }^{7}$, Mariusz Lamentowicz'1, \\ Andrew Macumber ${ }^{8,9}$, Yuri Mazei10,11, Edward A. D. Mitchell12,13, Nawaf A. Nasser ${ }^{9}$, \\ R. Timothy Patterson ${ }^{9}$, Helen M. Roe ${ }^{8}$, David Singer ${ }^{5}$, Andrey N. Tsyganov ${ }^{10,11}$ and \\ Bertrand Fournier ${ }^{14}$

\begin{abstract}
${ }^{1}$ Climate Change Ecology Research Unit, Faculty of Geographical and Geological Sciences, Adam Mickiewicz University, Poznań, Poland, ${ }^{2}$ CNRS, Laboratoire d'Ecologie Fonctionnelle et Environnement, Université de Toulouse, Toulouse, France, ${ }^{3}$ Institute of Parasitology, Biology Center, Czech Academy of Sciences, Ceské Budejovice, Czechia, ${ }^{4} \mathrm{~J}$. F. Blumenbach Institute of Zoology and Anthropology, University of Göttingen, Göttingen, Germany, ${ }^{5}$ Department of Zoology, Institute of Biosciences, University of São Paulo, São Paulo, Brazil, ${ }^{6}$ Real Jardín Botánico, CSIC, Madrid, Spain, ${ }^{7}$ Warsaw, Poland, ${ }^{8}$ School of Natural and Built Environment, Queen's University Belfast, Belfast, United Kingdom, ${ }^{9}$ Ottawa-Carleton Geoscience Centre, Department of Earth Sciences, Carleton University, Ottawa, ON, Canada, ${ }^{10}$ Department of General Ecology and Hydrobiology, Lomonosov Moscow State University, Moscow, Russia, " and Evolution, Russian Academy of Sciences, Moscow, Russia, ${ }^{12}$ Laboratory of Soil Biodiversity, Institute of Biology, University of Neuchâtel, Neuchâtel, Switzerland, ${ }^{13}$ Jardin Botanique de Neuchâtel, Neuchâtel, Switzerland, ${ }^{14}$ Institute of Environmental Science and Geography, University of Potsdam, Potsdam, Germany
\end{abstract}

\section{OPEN ACCESS}

Edited by:

Anne Elisabeth Bjune,

University of Bergen, Norway

Reviewed by:

O. Roger Anderson,

Lamont-Doherty Earth Observatory

(LDEO), United States

Claudia Bonecker,

State University of Maringá, Brazil

*Correspondence:

Katarzyna Marcisz

marcisz@amu.edu.pl

Specialty section:

This article was submitted to

Paleoecology,

a section of the journal

Frontiers in Ecology and Evolution

Received: 24 June 2020 Accepted: 17 September 2020

Published: 20 October 2020

Citation:

Marcisz K, Jassey VEJ,

Kosakyan A, Krashevska V, Lahr DJG,

Lara E, Lamentowicz $t$, Lamentowicz M, Macumber A, Mazei Y, Mitchell EAD, Nasser NA, Patterson RT, Roe HM, Singer $D$, Tsyganov AN and Fournier B (2020) Testate Amoeba Functional Traits and Their Use in Paleoecology.

Front. Ecol. Evol. 8:575966. doi: $10.3389 /$ fevo.2020.575966
This review provides a synthesis of current knowledge on the morphological and functional traits of testate amoebae, a polyphyletic group of protists commonly used as proxies of past hydrological changes in paleoecological investigations from peatland, lake sediment and soil archives. A trait-based approach to understanding testate amoebae ecology and paleoecology has gained in popularity in recent years, with research showing that morphological characteristics provide complementary information to the commonly used environmental inferences based on testate amoeba (morpho-)species data. We provide a broad overview of testate amoeba morphological and functional traits and trait-environment relationships in the context of ecology, evolution, genetics, biogeography, and paleoecology. As examples we report upon previous ecological and paleoecological studies that used trait-based approaches, and describe key testate amoebae traits that can be used to improve the interpretation of environmental studies. We also highlight knowledge gaps and speculate on potential future directions for the application of trait-based approaches in testate amoeba research.

Keywords: protists, functional traits, morphological traits, ecology, peatlands, lakes, soils, trait-based approaches

\section{INTRODUCTION}

Paleoecological reconstructions based on subfossil species assemblage data are commonly used to reconstruct past environmental changes over long time-scales (from hundreds of years to millennia) (Willis and MacDonald, 2011; Roberts, 2013). Assuming that species ecological requirements are stable over time, the main premise in paleoecology is that changes in species assemblages over time similarly reflect past environmental changes within a study site or region (Birks et al., 2016). While this approach informs on changes in key abiotic drivers of ecosystem processes (e.g., peatland water table depth, air temperature, $\mathrm{pH}$, nutrient loading, road salt and 
metal contamination in lakes), it does not provide direct evidence for functional changes. The functional trait approach aims to link community composition to ecological drivers and the functional consequences of these changes. This approach, which was first developed to better understand modern community structure has been increasingly used to infer long-term changes in ecosystem functioning (Walker and Cwynar, 2006; Luoto and Ojala, 2018; Peppe et al., 2018; van der Sande et al., 2019).

A functional trait, as defined by Violle et al. (2007), is any morphological, physiological or phenological feature measurable (or identifiable) at the individual level. These measurements need not refer to environmental variables or any other levels of organization (population, community, or ecosystem) (McGill et al., 2006; Violle et al., 2007; Nock et al., 2016; Céréghino et al., 2018). As such, functional traits can vary both within (intraspecific) and between (interspecific) species and can be further classified into two categories: (1) effect traits, which drive these changes in ecosystem functions; and (2) response traits, which drive the response of community structure to changes in environmental conditions (Lavorel and Garnier, 2002; Naeem and Wright, 2003; Suding et al., 2008). Response traits are adaptive to a specific environmental pressure, as they provide a higher fitness to the organisms that possess it.

Trait-based approaches are used to gain a mechanistic understanding of key processes in community ecology (Díaz and Cabido, 2001). They have predictive capabilities, and as such, have been adopted by a wide array of researchers through the last decade to, for example, explain the distribution of species along various abiotic gradients (e.g., Kaustuv et al., 2001; Berg et al., 2010; Diamond et al., 2011), the processes underlying the assembly of species into communities (e.g., Kraft et al., 2008; Jung et al., 2010; Kraft and Ackerly, 2010), the relationship between ecological community structure and ecosystem functions and services (e.g., de Bello et al., 2010; Lavorel and Grigulis, 2012; Robleńo et al., 2018), and the impact of climate change on species assemblages (Bjorkman et al., 2018; Henn et al., 2018). The response/effect traits framework has been used in various fields including ecological restoration (Laughlin, 2014), environmental change prediction (Suding et al., 2008), and ecosystem services (Lavorel and Grigulis, 2012). In general, trait-based approaches are expected to lead to generalized predictions across organizational and spatial scales, independent of taxonomy (Shipley et al., 2016; Robroek et al., 2017). Across fossil records, species are gained or lost, and are sometimes not easy to identify due to non-optimal preservation of fossil material. However, certain traits remain and can be similarly influenced by environmental conditions regardless of species identity. Therefore, the trait approach is a powerful way of gaining insight on how past changes influenced communities functions and related ecological processes (Lamentowicz et al., 2019). In turn, its use may improve predictions on how future species assemblages and their function will change along with current climate change in response to emerging environmental stressors (e.g., climate change; Heilmeier, 2019).

The first trait-based paleoecological studies focused on plant macrofossils and pollen, and explored the response of life-history traits to environmental and climate changes (Lacourse, 2009;
Butterfield et al., 2019; Birks, 2020). Trait-based approaches appeared to be particularly suited for application to testate amoebae, a polyphyletic group of protists. These unicellular amoeboid organisms are protected by a test (shell), whose shape, ornamentation and composition are characteristic for each species and used for morphology-based species identification. The tests can be preserved over millennia in peat (Charman, 2001) and lake sediments (Patterson and Kumar, 2002), and fossils strikingly similar to some modern taxa date to the Neoproteozoic (Porter and Knoll, 2000; Porter et al., 2003; Porter, 2011). Past environmental conditions can be inferred based on the observation of testate amoeba community makeup and previous knowledge on individual species ecological requirements. Testate amoebae are commonly used as proxies for peatland water table depth (DWT; Booth, 2002; Booth et al., 2004) and $\mathrm{pH}$ (Booth, 2001), the two major environmental gradients in peatlands (Hájek et al., 2006; Rydin and Jeglum, 2006), as well as lake trophic status (Patterson et al., 2012; Watchorn et al., 2013; Nasser et al., 2020b). Testate amoeba community composition data and associated measurements of environmental variables have been used to determine the environmental preferences of each species. Training sets have been developed across different geographical regions for both peatland and lake taxa in both the Northern and the Southern Hemisphere (Woodland et al., 1998; Wilmshurst et al., 2003; Lamentowicz and Mitchell, 2005; Booth, 2008; Patterson et al., 2012; Qin et al., 2012). These have been used to develop statistical models (transfer functions) for the reconstruction of longterm environmental changes based on species community data (Birks, 2012).

Testate amoeba tests can be used to measure several morphological traits, while knowledge of species' ecological preferences can provide additional relevant measures, e.g., trophic status of particular species or their hydrological preferences (Fournier et al., 2012; Céréghino et al., 2018). As such, testate amoeba functional traits in lake sediment and peat records constitute unique ecological archives of past changes in community structure that can be related to past environmental conditions and/or ecosystem functions. Several studies have successfully used trait-based approaches to investigate past trends in functional diversity (Marcisz et al., 2020), and to reconstruct past environmental conditions (Fournier et al., 2015; Lamentowicz et al., 2015; Marcisz et al., 2016; Gałka et al., 2017; van Bellen et al., 2017). This review summarizes the current knowledge of functional traits in testate amoebae and outlines some open questions and options for future applications in paleoecology.

\section{Benefits of Testate Amoeba Functional Trait-Based Approaches in Paleoecology}

In the specific context of paleoecology, the use of testate amoeba trait-based approaches has several notable advantages:

(1) Improved mechanistic understanding and predictability of ecological processes. Testate amoebae are important top predators in the microbial food web (Gilbert and Mitchell, 2006; Jassey et al., 2013b). They contribute to soil nutrient 
cycling (Wilkinson and Mitchell, 2010), especially the cycles of C, N, and Si in soils (Schröter et al., 2003; NguyenViet et al., 2004; Aoki et al., 2007; Jassey et al., 2015; Puppe, 2020). Their community structure is also strongly correlated to peatland water table depth, soil moisture regime (Woodland et al., 1998; Mitchell et al., 1999; Sullivan and Booth, 2011), shade/hydrology (Marcisz et al., 2014b; Lamentowicz et al., 2020), and chemistry (Tolonen et al., 1992; Hajkova et al., 2011; Singer et al., 2018); contaminant runoff into lakes (Neville et al., 2014; Roe and Patterson, 2014; Gavel et al., 2018); sea level change (Patterson et al., 1985; Charman et al., 1998, 2002); and has been shown to respond to experimental water table changes both in the field (Marcisz et al., 2014a) and in mesocosm studies (Koenig et al., 2017, 2018b). Testate amoeba community dynamics and how they relate to ecosystem functions is a dynamic field of research, although many knowledge gaps remain (but see Fournier et al., 2012; Jassey et al., 2013a, 2015; Lamentowicz et al., 2013a; Macumber et al., 2017). Investigation of past long-term changes in both testate amoeba assemblages and traits could be used to better understand community assembly rules, traitfiltering over time, and - most importantly - the possible existence of critical transitions of community functions, and thus of past ecosystem functioning. This would help to better understand current community dynamics and enable predictions of future environmental changes under ongoing global warming.

(2) Independence from taxonomic bias and improved transferability of models across biogeographic regions and temporal and spatial scales. Most soil life have not yet been described and this knowledge gap is larger for the smaller organisms (prokaryotes, protists and other microeukaryotes) (Decaëns, 2010). Testate amoebae have been thoroughly studied due to the well-defined morphological characteristics of the test that usually permits species-level identification for living and dead specimens. Their morphological identification can thus be considered simpler than for many other microbial groups. However, species boundaries, and the definition of species (Schlegel and Meisterfeld, 2003) requires additional research. Morphologic analysis and more recently molecular analysis has explored the phenotypic plasticity and cryptic diversity among several groups (Medioli et al., 1987; Wanner, 1999; Kosakyan et al., 2012; Singer et al., 2018; Macumber et al., 2020). This clearly illustrates the need for basic taxonomic research as a prerequisite for interpretations of the ecology and/or biogeography of taxa (Heger et al., 2009). The degree to which current taxonomic issues undermine the use of testate amoebae in palaeoecology is unclear, but in silico experiments in which the identity of morphologically similar species was switched, showed the potentially significant impact of inadequate baseline taxonomic research (Payne et al., 2011). One informal solution to overcome this problem would be to lump species into morphospecies and species complexes in ecological and paleoecological studies.
This approach is principally used with small taxa, e.g., reporting Corythion and Trinema species as CorythionTrinema type although they can be identified based on scale shape (oval vs. round) (Charman et al., 2000; Amesbury et al., 2016, 2018). However, merging taxa into larger complexes or morphospecies that possess different functional traits results in the loss of potentially useful ecological information, especially when focusing on species responses along narrow ecological gradients. Moreover, using a lower taxonomic resolution in paleoecological studies makes it impossible to fully exploit insights derived from observational or experimental studies that would have been possible if a higher taxonomic resolution was used. As described below in section "Lacustrine Environments" another approach widely utilized since the 1980s within the lacustrine testate amoebae research community is to designate informal infrasubspecific 'strains' associated with test morphologies, not necessarily linked to formal taxa, but which can be linked to specific environmental stressors. During multivariate statistical analysis, this ecophenotypic approach permits delineation of subtle environmental gradients that would not otherwise be possible (Patterson and Kumar, 2002). Alternatively, using testate amoebae functional traits in addition to, and not instead of, species data in paleoecology provides complementary information and reduces the risk associated with taxonomic confusion as the measurements of traits are less ambiguous than formal taxonomic criteria. The resulting transfer functions would potentially enable broader interpretations of community changes and functional processes over long time-scales.

(3) A useful additional tool for multi-proxy paleoecological reconstructions. Paleoecological investigations and interpretations often use several biological and geochemical proxies to obtain a wide range of information about past environmental changes. For instance, pollen, spores, plant macrofossils, and charcoal are commonly analyzed to reconstruct past vegetation changes, fires, and human impact over time (Schwörer et al., 2014; Feurdean et al., 2020), whereas geochemical data are used to assess changes in entire lake basins (Bonk et al., 2016; Lu et al., 2017; Jensen et al., 2020). Within projects involving a multi-proxy approach testate amoeba species assemblage data provide quantitative hydrological (e.g., Mitchell et al., 2001; Booth et al., 2012; Lamentowicz et al., 2015) and pH (Mitchell et al., 1999; Lamentowicz et al., 2008; Patterson et al., 2013); road salt contamination (e.g., Roe et al., 2010); nutrient loading (e.g., Patterson et al., 2012; Gavel et al., 2018), and mining induced metal contamination (e.g., Kihlman and Kauppila, 2009, 2010; Nasser et al., 2020b) reconstructions. Integrating traitbased approaches in multi-proxy investigations can provide information on ecological processes and may also help to elucidate functional roles based on correlations with other proxies. These then need to be tested in observational or experimental studies, illustrating a linkage between neo-ecology and paleoecology (Hunter, 1998; Rull, 2010; 
Buma et al., 2019). Moreover, multi-proxy data can elucidate long-term trait-environment relationships, giving an insight into eco-evolutionary processes at time scales beyond the range of ecological studies.

\section{A Functional Characterization of Testate Amoebae}

Functional traits have been well studied in various taxonomic groups such as plants (Weiher et al., 1999; Diaz et al., 2004; Wright et al., 2004; Cornwell et al., 2008; Kleyer et al., 2008; Kattge et al., 2020), invertebrates (Andriuzzi and Wall, 2018; Céréghino et al., 2018), birds (Bregman et al., 2014), and mammals (Porto et al., 2013). In the case of testate amoebae, some functional traits relevant to understanding the response of these organisms to environmental changes and their functional role in the soil ecosystem have also been identified (Fournier et al., 2012, 2015; Jassey et al., 2013a, 2015, 2016; Lamentowicz et al., 2015; Marcisz et al., 2016; Koenig et al., 2017). Traits can be measured on tests preserved in lake sediments and peat and are thus relevant for paleoecological studies. However, much work still needs to be done to: (1) quantitatively link these traits to organisms' fitness under different conditions; (2) assess tradeoffs among functional traits; (3) identify effect traits of specific ecosystem functions; (4) resolve the problem of collinearity among traits (cf. Lamentowicz et al., 2015); and (5) to relate traits to key factors such as climate.

Trait-based approaches have been increasingly applied in testate amoeba studies. It is therefore useful to provide a synthesis of the field of testate amoeba functional ecology and paleoecology and to outline some proposed future research avenues. Section "Current Knowledge and Characterization of Traits of Testate Amoebae" presents the current state of knowledge about testate amoeba traits linked to ecological, evolutionary, genetic and biogeographic contexts. Section "Description of Key Testate Amoeba Traits for Paleoecology" highlights the key traits and their significance to paleoecology, showcases the potential of using traits in long-term studies, emphasizes both the advantages, as well as the strengths and limitations of their application in paleoecology. Section "Conclusion, Knowledge Gaps and Perspectives for the Use of Testate Amoeba Traits in Paleoecology" summarizes knowledge gaps and future perspectives for the use of testate amoeba traits in paleoecology. A list of relevant testate amoeba functional traits and their characterization are presented in Table 1 and Figures 1-3.

\section{CURRENT KNOWLEDGE AND CHARACTERIZATION OF TRAITS OF TESTATE AMOEBAE}

\section{Testate Amoeba Traits and Ecological Roles Before "Functional Traits"}

Early ecological studies on testate amoebae assessed the distribution of species in various ecosystems and later attributed the environmental gradients to which particular species assemblages were correlated (Penard, 1902; Harnisch, 1925;
Sandon, 1927). The traits of testate amoebae in these studies were generally based on their taxonomic descriptions, in the context of well-defined, measurable taxonomy, usually based at the individual level and used comparatively across species (Nock et al., 2016). At the same time, the first attempts were made to develop ecological typologies of plant and animal species aimed at associating the performance of different species to ecologically relevant features of their morphology or physiology. The terms "guilds" (Schimper, 1903; Clements, 1905) and "life forms" (Raunkiaer, 1934) were introduced first by plant ecologists and similar attempts were subsequently made by zoologists e.g., Koepcke (1956), see Laureto et al. (2015). Unfortunately, the available information relating to the ecological preferences of testate amoebae was insufficient then to make any broad generalizations; therefore their functional role in ecosystem processes was rarely explicitly stated. For example, Deflandre (1937) reported that the largest species of all genera were purely aquatic. Other, early community ecology studies identified soil water content and $\mathrm{pH}$ as important factors explaining the distribution of testate amoebae in Sphagnum bogs (Bartoš, 1940, 1946; de Graaf, 1956, 1957; Bonnet, 1961a). Several studies observed that the variation in test size of certain species was related to the water content of the habitat (Jung, 1936; Heal, 1961, 1963). Bonnet (1961a) recognized that the tests of soil-dwelling testate amoebae were not only smaller in size than those from wetter biotopes, but that they were also different in shape. He observed that in wet Sphagnum mosses, tests were generally ovoid or pyriform, whereas in dry mosses and soils they are hemispherical or sub-hemispherical. Bonnet (1959) also noted that soil-dwelling species of Centropyxis Stein, 1859 lacked the characteristic hollow "horns" commonly found in aquatic species (e.g., C. aculeata Ehrenberg, 1832).

By the mid-1970s the terms "guild" (Root, 1967) and "functional groups" (Cummins, 1974) were formalized in ecological studies with the latter term having a more general connotation [see Blondel (2003) for a discussion of the key differences between the terms]. In line with this approach, Bonnet (1975) classified testate amoebae into sixteen morphological types according to the shape and symmetry of the tests and the structure of the aperture (or pseudostome). The morphological types were found to be closely related to the habitat types and could be used as indicators of ecological conditions and in understanding morphological evolutionary trends (Schönborn, 1989). For instance, species with a terminal and comparatively large aperture of acrostomic and trachelostomic morphological types were observed to be dominant in aquatic habitats and wet mosses. In dry habitats the proportion of species with a slitlike opening (compressed acrostomic type), with an aperture covered by an anterior visor or lip (plagiostomic or cryptostomic types) or by modified complex structures (propylostomic and diplostomic types) was found to be higher. The cotylostomic morphotype was determined to be characterized by an enlarged collar around the aperture which is used for fixation in unstable coastal marine interstitial biotopes (Schönborn, 1989). However, the application of this classification in subsequent functional ecology studies was limited. 
TABLE 1 | List of relevant testate amoeba functional traits explored so far in ecological and palaeoecological studies.

\begin{tabular}{lll}
\hline Trait (unit; if relevant) Description & $\begin{array}{l}\text { Trait function, ecological meaning, link to ecosystem Used in paleo? References } \\
\text { functions (if known) }\end{array}$
\end{tabular}

\begin{tabular}{lll}
\hline $\begin{array}{l}\text { Test (shell) size } \\
\text { Biovolume }\left(\mu \mathrm{m}^{3}\right)\end{array} \quad$ Volume of the test & $\begin{array}{l}\text { Related to the metabolic rate } \\
\text { and the capacity of the food } \\
\text { web to process energy }\end{array}$ & $\begin{array}{l}\text { Size features of testate amoebae are } \\
\text { linked to dissolved organic carbon and } \\
\text { nitrogen in peatlands, and thus related } \\
\text { to } \mathrm{C} \text { and nitrogen cycles. Small species } \\
\text { better overcome difficult conditions and }\end{array}$ \\
& $\begin{array}{l}\text { colonize new habitats faster than large } \\
\text { ones as they are lighter }\end{array}$
\end{tabular}

\section{Length/size/shell size Length of the test \\ $(\mu \mathrm{m})$}

Height $(\mu \mathrm{m})$

Width/breadth ( $\mu \mathrm{m})$

Diameter ( $\mu \mathrm{m})$

Body range $(\mu \mathrm{m})$

Centroid size

\section{Test construction}

Test material origin/

composition/type

\section{Height of the test}

Width of the test

Diameter of the test

(body length species $\mathrm{x}$ - maximum

body length within the

community)/minimum body length

within the community

Geometric morphometrics: square roo

of the non-weighted sum of squared

distances from the joint centroid to

landmarks.

(1) tests made of secreted biosilica plates (idiosomes), (2) organic-coated idiosomes (tests with thick organic coating), (3) proteinaceous tests, (4) tests built from recycled organic or mineral particles (xenosomes, agglutinated)
Larger taxa have longer

generation times than smal taxa and are thus expected both to be more sensitive to perturbation and to recove more slowly from perturbations

$-$

Large, pyriform taxa are associated with low nutrients, benthic habitats and mixotrophy.

May allow an environmenta filter to operate, in relation to the availability of the different substrates (e.g., mineral particles of adequate size, fungal hyphae, silica) or the relative cost of building a

self-secreted test by

comparison with an

agglutinated one; Availability of

material and/or prey to

construct the test. Source of

material appear to be a major

regulator of abundance and

repartition of testate amoeba

along Sphagnum
Lousier, 1974; Wanner and Xylander, 2005; Laggoun-Défarge et al., 2008; Fournier et al 2012, 2015; Jassey et al., 2013a,b, 2016; Fiałkiewicz-Kozieł et al., 2015; Lamentowicz et al., 2015; Arrieira et al., 2016; Krashevska et al., 2016, 2020; Marcisz et al., 2016, Marcisz et al., 2020; Gałka et al., 2017; Koenig et al., 2017, 2018a,b; McKeown et al., 2019; Macumber et al., 2020

Lamentowicz et al., 2009a; Fournier et al., 2012; Gomaa et al., 2012; Fiałkiewicz-Kozie et al., 2015; Krashevska et al., 2016, 2020; Schwind et al., 2016a,b; Koenig et al., 2017, 2018a,b; van Bellen et al., 2018; Marcisz et al. 2019,2020 
TABLE 1 | Continued

\begin{tabular}{|c|c|c|c|c|}
\hline Trait (unit; if relevant) & Description & $\begin{array}{l}\text { Trait function, ecological meaning, link to ecosystem } \\
\text { functions (if known) }\end{array}$ & Used in paleo? & References \\
\hline \multirow[t]{2}{*}{ Test shape/morphology/outline } & $\begin{array}{l}\text { Test shapes: discoid, pyriform, globular, } \\
\text { circular, oviform, flask-shaped }\end{array}$ & $\begin{array}{l}\text { In lake Arcellinida, taxa with discoid and hemispherical } \\
\text { tests are associated with planktic/epiphytic habitats. }\end{array}$ & No & $\begin{array}{l}\text { Gomaa et al., 2012; Lansac-Tôha et al., 2014; } \\
\text { Lahr et al., 2019; Krashevska et al., 2020; } \\
\text { Macumber et al., } 2020\end{array}$ \\
\hline & $\begin{array}{l}\text { Geometric morphometrics: principal } \\
\text { component scores and shape models. }\end{array}$ & $\begin{array}{l}\text { In lake Arcellinida, taxa with } \\
\text { large pyriform tests are } \\
\text { associated with oxygenated } \\
\text { benthic habitats, taxa with } \\
\text { oviform tests with epiphytic } \\
\text { habitats, and taxa with globular } \\
\text { tests with planktic/epiphytic } \\
\text { habitats. }\end{array}$ & Yes & Macumber et al., this issue \\
\hline Presence of a neck & Yes or no & Important trait in Arcellinida & No & Gomaa et al., 2012; Lahr et al., 2019 \\
\hline Test compression & $\begin{array}{l}\text { Compressed, sub-spheric, spheric, } \\
\text { hemispherical }\end{array}$ & $\begin{array}{l}\text { An adaptation to living in a thin } \\
\text { water film and allowing the } \\
\text { amoebae to remain active } \\
\text { longer when the soil moisture } \\
\text { content decreases; Survival } \\
\text { potential in drier situations and } \\
\text { thus potential contribution to } \\
\text { the food web in dry conditions }\end{array}$ & Yes & $\begin{array}{l}\text { Lousier, 1974; Fournier et al., 2012, 2015, } \\
\text { 2016; Koenig et al., 2017, 2018a; Krashevska } \\
\text { et al., } 2020\end{array}$ \\
\hline \multicolumn{5}{|l|}{ Test aperture (pseudostome) } \\
\hline Aperture position & $\begin{array}{l}\text { Position of the aperture within the test: } \\
\text { acrostomic, plagiostomic, axial }\end{array}$ & $\begin{array}{l}\text { Protected/hidden apertures are } \\
\text { interpreted as adapted to } \\
\text { decreasing soil moisture } \\
\text { content; Aperture position } \\
\text { represents the ability to survive } \\
\text { in thin water film and thus the } \\
\text { ability to remain active and }\end{array}$ & Yes & $\begin{array}{l}\text { Bonnet, 1964; Lousier, 1974; Chardez and } \\
\text { Lambert, 1981; Laggoun-Défarge et al., 2008; } \\
\text { Fournier et al., 2012; Krashevska et al., 2012, } \\
\text { 2020; Jassey et al., 2013a,b; Fiałkiewicz-Kozieł } \\
\text { et al., 2015; Fournier et al., 2015; Lamentowicz } \\
\text { et al., 2015; Marcisz et al., 2016; Koenig et al., } \\
\text { 2017, 2018a,b; Marcisz et al., } 2020\end{array}$ \\
\hline
\end{tabular}

Aperture shape Shape of the aperture can be circular,

oval, slit-like, irregular

contribute to the food web in

dry conditions

In lake Arcellinda, Netzelia sp.

with teeth-like apertures have

been observed to be planktic

carnivores and have been

found to be associated with the

rise of other planktic carnivores

such as Daphnia sp.

highlighting success of strategy.

Related to prey size and food

web functioning 2013; Gomaa et al., 2014; Fournier et al., 2015; Marcisz et al., 2016; Koenig et al., 2017. 2018a,b; Krashevska et al., 2020; Marcisz et al., 2020

Macumber et al , this issue; Lahr et al., 2019; Krashevska et al., 2020 
TABLE 1 | Continued

\begin{tabular}{|c|c|c|c|c|}
\hline $\begin{array}{l}\text { Trait (unit; if } \\
\text { relevant) }\end{array}$ & Description & $\begin{array}{l}\text { Trait function, ecological meaning, link to ecosystem } \\
\text { functions (if known) }\end{array}$ & Used in paleo? & References \\
\hline \multicolumn{5}{|l|}{ Phylogeny } \\
\hline $\begin{array}{l}\text { Pseudopod } \\
\text { type }\end{array}$ & Lobose, filose & $\begin{array}{l}\text { This trait was used as } \\
\text { lobose/filose TA index where } \\
\text { lobose TA represent K-strategic } \\
\text { species whereas filose TA } \\
\text { represent } r \text {-strategic species. } \\
\text { More developed communities } \\
\text { are dominated by K-strategic } \\
\text { lobose TA. }\end{array}$ & No & $\begin{array}{l}\text { Mattheeussen et al., 2005; Wanner and Xylander, } \\
\text { 2005; Beyens et al., 2009; Fournier et al., 2012; }\end{array}$ \\
\hline Phylogeny & $\begin{array}{l}\text { Euglyphida vs. Arcellinida; "Pyriform" } \\
\text { vs. "Lanceolate" vs. Other }\end{array}$ & $\begin{array}{l}\text { Different evolutionary stable } \\
\text { strategy to cope with } \\
\text { environmental settings }\end{array}$ & No & $\begin{array}{l}\text { Fournier et al., 2012; Krashevska et al., 2020; } \\
\text { Macumber et al., } 2020\end{array}$ \\
\hline \multicolumn{5}{|l|}{ Trophy } \\
\hline $\begin{array}{l}\text { Trophic status } \\
\text { (heterotrophy/ } \\
\text { mixotrophy) }\end{array}$ & $\begin{array}{l}\text { Presence or not of photosynthetic } \\
\text { endosymbionts }\end{array}$ & $\begin{array}{l}\text { Mixotrophy is strongly related to } \\
\text { the presence of wet Sphagnum } \\
\text { and carbon sequestration in } \\
\text { peatlands. It can also be used } \\
\text { as a proxy for species survival } \\
\text { in extremely oligotrophic } \\
\text { conditions in Sphagnum } \\
\text { capitula. Among lake } \\
\text { Arcellinida, mixotrophy, } \\
\text { especially in large pyriform taxa } \\
\text { may indicate oligotrophy, clear } \\
\text { water and an oxygenated } \\
\text { benthic environment. }\end{array}$ & Yes & $\begin{array}{l}\text { Heal, 1964; Schönborn, 1965; Yeates and } \\
\text { Foissner, 1995; Gillbert et al., 2000, 2003; Jassey } \\
\text { et al., 2012, 2015; Krashevska et al., 2012, 2020; } \\
\text { Marcisz et al., 2014b, 2015, 2016, 2019, 2020; } \\
\text { Fournier et al., 2015; Payne et al., 2016; Gałka } \\
\text { et al., 2017; Koenig et al., 2017, 2018a,b; Ratcliffe } \\
\text { et al., 2017; Creevy et al., 2018; van Bellen et al., } \\
\text { 2018; Herbert et al., 2019; Basińska et al., 2020; } \\
\text { Lamentowicz et al., 2020; Macumber et al., 2020, } \\
\text { this issue; Zhang et al., 2020a,b }\end{array}$ \\
\hline Trophic level & $\begin{array}{l}\text { Species with a low test-aperture size } \\
\text { over body size ratio are considered as } \\
\text { having low trophic position } \\
\text { (bacterivores, algivores), whereas } \\
\text { species with high ratio as having a high } \\
\text { trophic position (predators of other } \\
\text { protists and micro-metazoans) }\end{array}$ & $\begin{array}{l}\text { Reflects the complexity of the } \\
\text { food web. Dominance of high } \\
\text { trophic level species points to a } \\
\text { more complex microbial food } \\
\text { web in the peatland. }\end{array}$ & No & $\begin{array}{l}\text { Jassey et al., 2012, 2013a,b, 2014, 2016; } \\
\text { Lamentowicz et al., 2013a; Fournier et al., 2016; } \\
\text { Payne et al., 2016; Creevy et al., } 2018\end{array}$ \\
\hline \multicolumn{5}{|c|}{ Ecological preferences } \\
\hline $\begin{array}{l}\text { Preferred DWT } \\
(\mathrm{cm})\end{array}$ & Wet vs. intermediate vs. dry indicators & & Yes & Marcisz et al., 2016; Krashevska et al., 2020 \\
\hline Preferred pH & $\begin{array}{l}\text { Species } \mathrm{pH} \text { preferences (higher or } \\
\text { lower } \mathrm{pH} \text { values) }\end{array}$ & & Yes & Marcisz et al., 2016; Krashevska et al., 2020 \\
\hline \multicolumn{5}{|l|}{ Other } \\
\hline Gas vacuoles & Presence or absence & $\begin{array}{l}\text { Structures used by testate } \\
\text { amoebae to move vertically in } \\
\text { the water column. They are } \\
\text { used to float the organism from } \\
\text { the bottom to the surface of the } \\
\text { water in an inverted position. }\end{array}$ & No & Ogden, 1991; Schwind et al., 2016b \\
\hline
\end{tabular}

volutionary stable

trategy to cope with

Mixotrophy is strongly related to

he presence of wet Sphagnum

in large pyriform taxa

ay indicate oligotrophy, clear

web. Dominance of high

ophic level species points to

ore complex microbial food

(bacterivores, algivores), wher

\section{Ecological preferences}




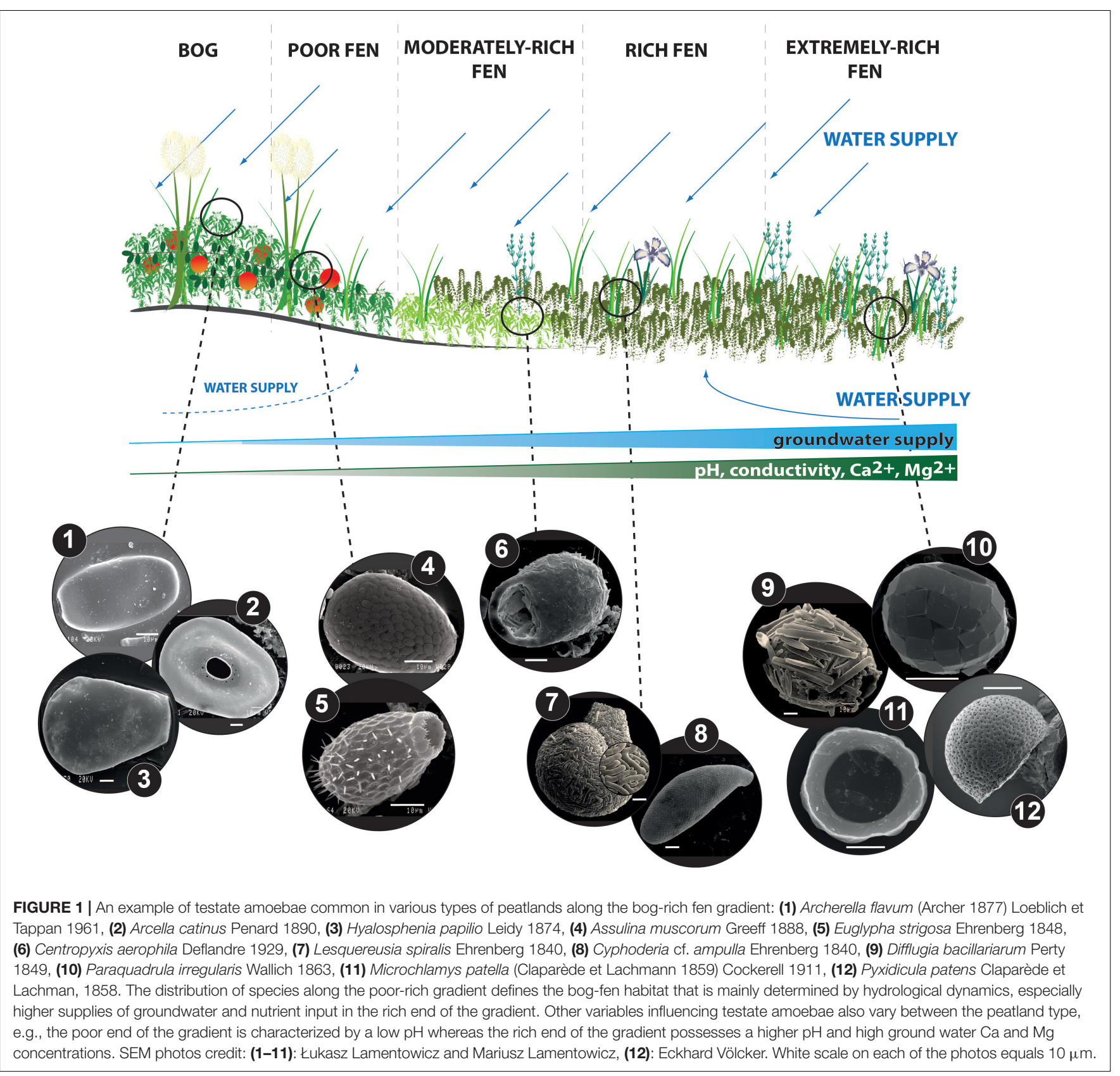

Knowledge of the feeding preferences and the functional role of testate amoebae in relation to nutrient cycling and primary production is scarce [see Wilkinson and Mitchell (2010) for an overview]. Six distinct feeding groups were identified that encompassed freshwater protozoa: photosynthetic autotrophs, bacterivores/detritivores, saprotrophs, algivores, non-selectiveomnivores and predators (Pratt and Cairns, 1985). These groups were also successfully applied to soil communities with the addition of the mycophagous group (Couteaux and Darbyshire, 1998). However, these generalizations have not been formulated for testate amoebae due to a lack of important basic knowledge for most taxa. Most testate amoebae are predators with their primary diet being comprised of a wide range of food sources including bacteria (Coûteaux and Pussard, 1983), other protists (Deflandre, 1936b; Gilbert et al., 2000), microalgae (Bles, 1929), fungi (Coûteaux and Dévaux, 1983) and small metazoa (i.e., rotifers, Mast and Root, 1916). Although prey size is often limited by the size of the aperture (Ogden and Hedley, 1980), testate amoebae are also able to feed on food sources much larger than themselves (e.g., filamentous algae, Stump, 1935). They also feed on prey such as significantly larger nematodes (Yeates and Foissner, 1995), which they have been observed to hunt in packs (Gilbert et al., 2000; Geisen et al., 2015). Schönborn et al. (1987) suggested that some species (i.e., Schoenbornia humicola Schönborn 1964) might also be saprophagic with different feeding phases. Bonnet (1958) and Heal (1964) found that light 


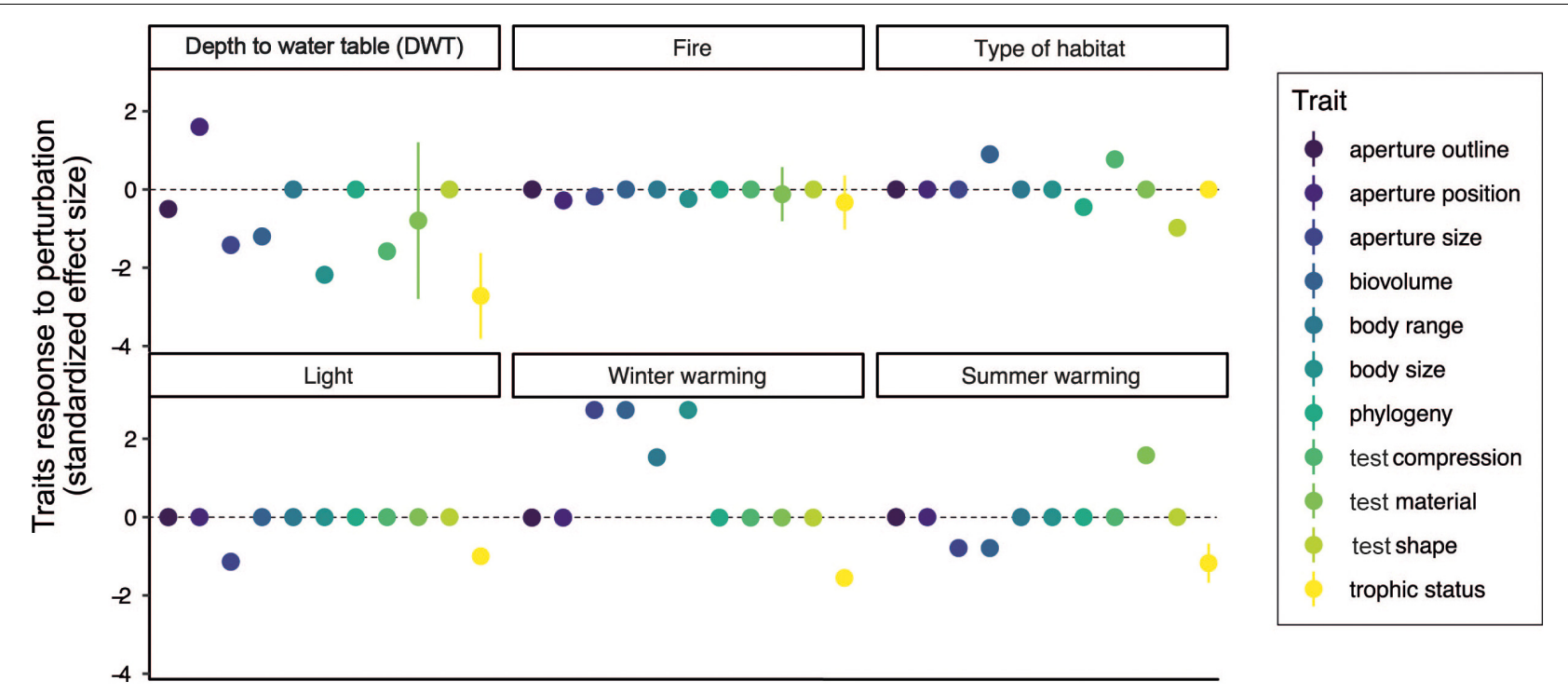

FIGURE 2 | Testate amoeba trait responses to environmental factors. Standardized effect size was calculated based on published testate amoeba trait studies that investigated the effect of various perturbations on testate amoeba trait composition.

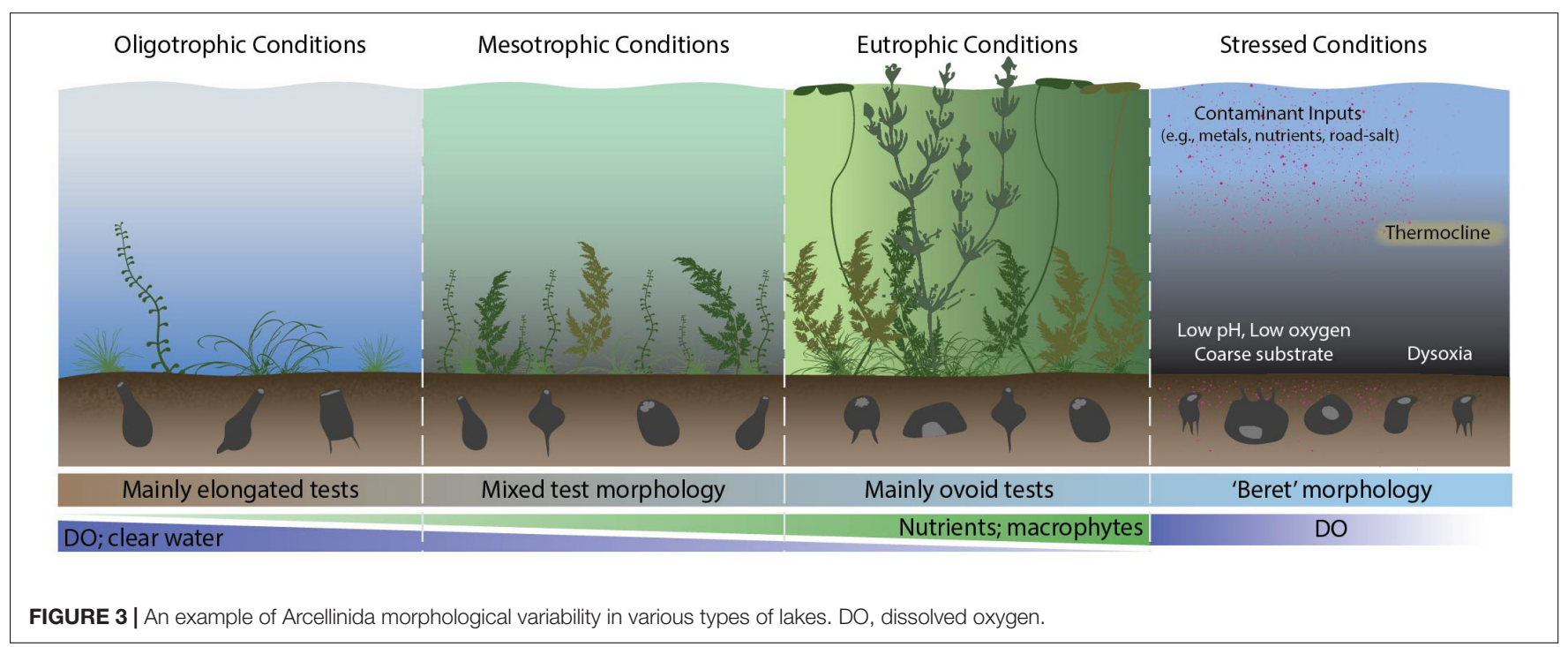

could determine the distribution of mixotrophic (zoochlorellae containing) species and Schönborn (1965) concluded that their occurrence was linked to the low nutrient content in Sphagnumdominated bogs. However, a quantitative determination of the contribution of mixotrophic taxa to primary production in bogs was only recently demonstrated (Jassey et al., 2015).

Bonnet (1976b) suggested that filose testate amoebae (e.g., Euglypha, Corythion, Trinema) were assumed to be $r$-strategists (i.e., small test size, short generation times, etc.), whereas lobose testate amoebae (e.g., Arcella, Nebela, Centropyxis, Difflugia) are in contrast $K$-strategists (larger test size, longer generation times, etc.) and introduced the L/F index to estimate the developmental stage of testate amoebae communities (or ecosystems). The $\mathrm{L} / \mathrm{F}$ index, which represents the relative proportion of lobose vs. filose testate amoebae, has been applied in ecological and paleoecological studies to estimate ecosystem resilience and recovery after perturbation (see details in section "Soil and Other Wetland Habitats"). Unfortunately, only a few species have been cultured in laboratory settings (Wanner, 1999), and further research is thus required to validate the assumption concerning the life strategies of testate amoebae (Creevy, 2013). That said, unpublished research based on cultures of $>100$ taxa indicates that rather than there being a "filose-lobose" difference in growth rates, the rate of growth seems to depend primarily on biovolume, with smaller species reproducing faster than larger ones. Unfortunately, most of this research data has not been published (Ralf Meisterfeld, personal communication). The most consistent attempt to classify testate amoebae following 
the concept of "vital attributes" (Noble and Slatyer, 1980) was undertaken by Jax (1992) in order to describe the succession and long-term dynamics within freshwater testate amoebae communities. In that work, testate amoebae were grouped according to their dispersion ability, the preference of particular successional phases and overall long-term ecosystem dominance. However, with only a few exceptions (e.g., Chardez, 1965; Raikov et al., 1989), there is a basic lack of information on the ability of most testate amoebae to, for example, form cysts, which is an important functional trait related to ecosystems resilience and recovery rate. Nevertheless, the available studies provide a considerable amount of data that can be used to infer the functional role of individual testate amoeba taxa, which can be considered within the frameworks of functional ecology to form the basis for future studies.

\section{Evolution vs. Testate Amoeba Morphological Traits}

Within the constraint of being unilocular, testate amoebae are characterized by a myriad of test morphologies that differ in general shape, size and composition, which are therefore useful for species identification. Additionally, Arcellinida testate amoebae have a very long fossil record that makes the group an important component of evolutionary studies on early eukaryotes (Schönborn et al., 1999; Porter and Knoll, 2000; Porter et al., 2003; Schmidt et al., 2006; Schmidt et al., 2010; Porter, 2011). Attempts to resolve the systematics and evolutionary relationships within the group began in the early 20th century (Deflandre, 1936a; Jung, 1942), and initially pseudopod morphology and test composition were used to classify testate amoebae into "filose" (euglyphids and amphitremids) and "lobose" (arcellinids), as well as the major suborders within these groups (Bovee, 1985; Meisterfeld, 2002).

Application of molecular methods changed the understanding of the deep evolutionary relationships within the testate amoebae resulting in several major taxonomic revisions. Studies based on single-gene phylogenetic reconstructions (i.e., SSU rRNA, mt COI) demonstrated that several genera (i.e., Nebela, Quadrulella, Difflugia) are paraphyletic, and that test morphology appeared to be one of the most consistent traits constraining deep phylogeny (Lara et al., 2008; Lahr et al., 2011; Gomaa et al., 2012). More recently, combined approaches using hundreds of genes as well as detailed morphological analyses have been used to more robustly reconstruct the major lineages within the Arcellinida (Lahr et al., 2019). In addition, reconstruction of ancient Tonian (Neoproterozoic, 730 million years ago) test morphologies of vase-shaped microfossils revealed that they display a remarkable similarity to modern arcellinidans (Lahr et al., 2019). These results, building on previous research, indicate that testate amoebae had already diversified before the beginning of the Sturtian glaciation, 717 million years ago (Porter and Knoll, 2000; Porter et al., 2003; Porter, 2011). The morphological diversity in place by the Neoproterozoic and apparent evolutionary conservatism since suggests that distinct functional types of testate amoebae related to ecological niches, feeding behaviors and distinct evolutionary strategies developed early in their evolutionary history (Lahr et al., 2019).
The recognition of arcellinidan cryptotaxa provides additional evidence of the important role of functional traits in constraining test morphology.

It can therefore be concluded that, at least in Arcellinida, test morphology has played a substantial role in shaping the evolution of testate amoebae. While the overall test outline is the most important trait defining deep phylogenetic groups, in some groups such as the Organoconcha, comprising genera Pyxidicula and Microchlamys, the characteristic very wide aperture may be of evolutionary significance. Furthermore, at the genus and species level other morphological traits can be equally important. For example, in the genus Quadrulella, the size and placement of siliceous test plates are species-specific (Kosakyan et al., 2016).

\section{Testate Amoeba Molecular Variability vs. Trait Variability}

Testate amoeba species identification based on test morphology has always been a challenge. Phenotypic plasticity is common among testate amoebae, making it difficult to determine valid morphological identification criteria (Medioli et al., 1987). Culturing studies by Jennings (1916) early on demonstrated the wide variation that could be observed within clonal lineages of Difflugia. Factors such as silicon availability (Wanner et al., 2016), food or temperature were shown experimentally to influence aperture shape and test size, both in the field (Wanner and Meisterfeld, 1994) and in vitro (Wanner, 1994). Given the importance of morphology-based taxonomic identification for applications such as paleoecology and biomonitoring (Mitchell et al., 2014), and the comparability of observations and experiments carried out within various research laboratories, taxonomic revisions, or the development of an alternative objective classification scheme is necessary. The existing testate amoeba classification schemes have been challenged by the results of molecular studies (see section "Evolution vs. Testate Amoeba Morphological Traits"). DNA barcoding of individual specimens based on variable mitochondrial markers has led to both the recognition of distinct new species within existing species complexes and the revision of phylogenetic relationships among taxa, which has further led to the description, or redefinition, of both genera and families (Singer et al., 2015; Kosakyan et al., 2016; Duckert et al., 2018). Of ecological relevance, some closely related and morphologically similar (pseudo-cryptic) species (e.g., Nebela guttata Kosakyan et Lara 2012 and Nebela gimlii Singer et Lara 2015) were shown to occupy different ecological niches (Singer et al., 2018). Hyalosphenia papilio Leidy, 1874, a common species in northern Sphagnum peatlands was found to be a species complex comprising at least 13 distinct genetic lineages with geographically limited distributions (Heger et al., 2013; Singer et al., 2019).

The unresolved state of testate amoeba taxonomy makes the use of morphology-based community descriptions particularly difficult, especially because closely-resembling species can occupy divergent niches and lumping them blurs taxon related ecological indication signals. In order to overcome these biases and to produce objective and comparable data, metabarcoding approaches are currently developed. Whole environmental DNA 
is extracted on concentrated testate amoeba cells, and a groupspecific PCR protocol is applied to obtain DNA sequences of the studied organisms (Kosakyan et al., 2015). These promising initiatives are however, at the moment, of limited applicability given the sparse molecular information available for most groups of testate amoebae; in the future, however, they could also be applied to fossil DNA. Likewise, in the future, tracking functional genes expressed by testate amoebae during identified and environmentally relevant processes within metatranscriptomes or ancient DNA metagenomes will probably increase the relevance of these protists as bioindicators (Kosakyan and Lara, 2019).

Trait analysis overcomes the biases linked to species identification, and importantly, can integrate any information derived from ecophenotypic plasticity. Likewise, a correspondence has been observed between measurable traits (such as test size and the number of pores) and climatic/environmental factors (Mulot et al., 2017). In addition, large test size has been reported as a trait related to humidity when considering the whole community in peatland settings (Koenig et al., 2018b), and climate variability in lacustrine Arctic studies (Dallimore et al., 2000). Paradoxically the largest species with the otherwise primarily wetland genus Quadrulella has been discovered in biocrusts from a Mexican tropical desert (albeit receiving substantial water through condensation; Pérez-Juárez et al., 2017).

These data are relevant for characterizing environmental change over time, but would be omitted in species only based studies, regardless of the level of taxonomic resolution analyzed. Studying the correspondence between observed traits, phylogenetic position and environmental factors is still a wide-open field of research. Sphagnum-associated species characterizing Palearctic peatlands are relatively well studied. However, many species may still be left to be described when taxonomists eventually take a closer look at individual species complexes (Kosakyan et al., 2016). Other biogeographic regions (e.g., the Neotropics), and other ecosystem types (e.g., rich fens) are still relatively less studied.

\section{Testate Amoeba Trait-Environment Relations in Different Habitats Sphagnum-Dominated Peatlands}

Studies on testate amoeba-environment relationships in Sphagnum-dominated peatlands have been mainly carried out on raised ombrotrophic bogs (but see Opravilova and Hajek, 2006; Hajkova et al., 2011). Peatlands of this type are highly acidic ( $\mathrm{pH} 3.5-5.5$ ), have no contact with groundwater, and are supplied exclusively by rainwater (Rydin and Jeglum, 2006). Therefore, they only receive allochthonous material from precipitation (rain and dry deposition) but not from e.g., ground water from catchment, streams or rivers. Those ombrogenic conditions result in rather straightforward species-environment relationships that are relatively easy to explore in comparison with other peatland types (e.g., fens, spring-fed fens or landslide mountain fens; Figures 1 and 2). Early studies mostly focused on the diversity and community composition of testate amoebae along ecological gradients (e.g., Heinis, 1910; Harnisch, 1927; Grospietsch, 1953; Warner, 1987), later leading to more quantitative and experimental studies (e.g., Tolonen et al., 1992; Warner and Chmielewski, 1992; Tolonen et al., 1994; Gilbert et al., 1998b; Mitchell et al., 1999). Most work on the ecology of peatland testate amoebae has focused on community patterns along the hydrological gradient (typically water table depth) and trophic gradients (typically $\mathrm{pH}$ ). However, other factors such as peatland type, landscape openness, light intensity/shading, nutrient concentration and temperature changes have also been studied (Figure 2). Most research aimed at understanding testate amoebae morphological traits and their relationship to environmental gradients and changes, and the functional implications of these changes has in fact focused on peatlands (Table 1):

(1) Trophic level and testate amoeba functional traits. Testate amoeba community composition plays an important role in regulating the peatland microbial food web structure (Gilbert et al., 1998a, 2003; Jassey et al., 2012, 2013a,b; Lamentowicz et al., 2013a; Meyer et al., 2013), with mounting evidences that shifts in microbial food web structure may be linked to shifts in the functional trait composition of testate amoebae (Jassey et al., 2013b; Lamentowicz et al., 2013a; Hamard et al., 2019). For instance, it has been recently shown that the loss of mixotrophic testate amoebae (Table 1) destabilizes peatland microbial food webs by changing trophic interactions and decreasing connectivity within the microbial network (Hamard et al., 2019). Other research has further demonstrated that shifts in environmental conditions select for testate amoeba taxa with either a high or low trophic level based on their body size features (Lamentowicz et al., 2013a; Jassey et al., 2014; Fournier et al., 2016). Functional trait shifts toward either high and low trophic level testate amoebae species has often been the consequence of abrupt environmental changes connected with natural or anthropogenic influence (Jassey et al., 2013a, 2016; Lamentowicz et al., 2013a; Meyer et al., 2013; Krashevska et al., 2016; Figure 2). Other studies along open-to-forested bog transects have further shown that tree encroachment reduces the trophic level of testate amoeba communities leading to an increased abundance of smaller species (Payne et al., 2016; Creevy et al., 2018). Loss of testate amoeba functional diversity and a decrease in abundance of larger species have also been linked to extreme weather conditions; harder soil frosts (Jassey et al., 2016) as well as warming (Jassey et al., 2013a), suggesting that smaller species are more resistant to extreme climatic condition. In New Zealand peatlands, smaller species were found to be more closely correlated to water table depth and conductivity while larger species were correlated to $\mathrm{pH}$, suggesting that these two components of the community may provide contrasting ecological signals (McKeown et al., 2019). Among direct anthropogenic impacts, atmospheric pollution has been shown to 
negatively influence high trophic level testate amoeba species (Meyer et al., 2012, 2013), again emphasizing the generally higher sensitivity of larger testate amoeba taxa to environmental disturbances (Table 1).

(2) Individual trait responses. There has been an increase in research through the last decade on assessing the response of individual testate amoeba functional traits to environmental changes in peatlands. To identify general patterns in trait responses to environmental changes, we summarized the responses of individual testate amoeba traits to disturbances (DWT change, warming, light intensity and habitat change) by calculating standardized effect sizes. To do so, coefficients of correlations and/or F-values were extracted from tables, figures, the main text and/or supplementary materials available in the literature. Then, $F$-values and/or coefficient of correlations were converted into an effect size using the compute.es package in $R$ ( $\mathrm{R}$ Development Core Team, 2020); the results are presented in Figure 2. Overall, this analysis revealed that testate amoeba traits strongly respond to DWT and warming, while fire, light intensity and habitat shift had only weak and/or specific effects on individual testate amoeba traits. We also observed a strong, and primarily negative, response for most testate amoeba traits to water level changes (Figure 2). Most studies (Fournier et al., 2012; Jassey et al., 2013a; Marcisz et al., 2014b; Koenig et al., 2017, 2018a,b) have reported a decrease in test size (length, width, range) with decreasing water level, while mixotrophic species tended to disappear (Figure 2). Documented effects on test material and type have been more variable, with sometimes conflicting results (Fournier et al., 2016), suggesting that some postulated trait-hydrology relationships may be context-dependent, and might be more closely related to the initial water levels and peatland trophic status. Often confounded with hydrology, the most recent analyses reported that light intensity and habitat shifts had similar effects, and that both were more strongly correlated than hydrology to testate amoeba traits such as trophic status and test characteristics (Marcisz et al., 2014b; Payne et al., 2016; Ratcliffe et al., 2017; Creevy et al., 2018; Herbert et al., 2019; Lamentowicz et al., 2020; Figure 2). Overall, such findings show that not only testate amoeba community structure (Charman and Warner, 1992; Mitchell et al., 1999; Lamentowicz and Mitchell, 2005), but also the testate amoeba functional traits present can be directly correlated to peatland hydrology (Lamentowicz et al., 2020). These results further support recent attempts of using testate amoeba functional traits in transfer function models to quantitatively reconstruct past water table levels (van Bellen et al., 2017). Besides hydrology, studies focusing on the impact of climate change effects (e.g., precipitation, fire) have shown that testate amoeba body size, aperture size and trophic status can commonly be correlated to environmental changes (Figure 2), with related potentially important impacts on food webs and biogeochemical cycles (Jassey et al., 2015; Basińska et al.,
2020). It has also been observed that the trophic status (i.e., mixotrophy) of testate amoebae is a sensitive trait to most environmental disturbances. The importance of mixotrophs for peatland carbon cycling (Jassey et al., 2015) and microbial food web structure (Hamard et al., 2019) confirms that investigations of testate amoeba functional traits are as important to consider as species taxonomy and morphology. Identifying dominant testate amoeba traits that respond to environmental changes over long timescales (hundreds of years to millennia) can potentially serve as a sensitive paleoenvironmental indicator (e.g., documentation of shift of Sphagnum peatlands from a carbon sink to a carbon source; Zhang et al., 2020a,b).

\section{Fens}

In contrast to ombrotrophic bogs, fens are characterized by the influence of ground or surface water, and hence are typically more minerotrophic. The dominant environmental gradients in fens are water $\mathrm{pH}$ and $\mathrm{Ca}$ content (Bridgham et al., 1996; Hájek et al., 2006, 2014; Hájková et al., 2012). Fens cover a much wider range of habitats and abiotic conditions than ombrotrophic bogs, ranging from Sphagnumdominated poor-fens to alkaline rich fens dominated by brown mosses (Gąbka and Lamentowicz, 2008) (Figure 1). This wider range of possible hydrological and hydrochemical conditions makes it more challenging to determine the testate amoeba species-environment relationships in fens than in ombrotrophic bogs. While testate amoeba community structure typically differs markedly between bogs and fens (Heal, 1961), some testate amoeba functional traits may be characteristic of both environments. For example, the abundance of mixotrophs and heterotrophs in peatlands differs along the poor-rich and wetness gradient, with higher abundances of mixotrophs in bogs and poor fens. Indeed, H. papilio and Archerella flavum (Archer 1877) tolerate slightly minerotrophic conditions such as existing in Sphagnum-dominated poor-fens where they can be very abundant, but they do not occur in calcium-rich fens dominated by brown mosses (Jassey et al., 2014).

Specific taxa restricted to extremely rich fens, such as Pyxidicula and Microchlamys, possess disk-like tests with a wide aperture (Figure 1). In Microchlamys patella (Claparède \& Lachmann 1859) for example, the cell is enclosed within a membranous sac, which is fixed to the test at several points, but is lost in empty tests (Siemensma, 2019). These species are associated with high groundwater $\mathrm{Ca}$ and $\mathrm{Mg}$ concentrations, and they often occur at the base of peat deposits, indicating the past presence of calcium-rich or extremely calcium-rich fen stages in the early development of some peatlands (Lamentowicz et al., 2013b; Gałka et al., 2017). The enriched part of the gradient (Lamentowicz et al., 2011) is typically characterized by Paraquadrula irregularis Wallich 1863, a small species that builds its test from secreted quadratic or rectangular calcite plates, as well as Quadrulella symmetrica (Wallich 1863) which produces siliceous square plates, regularly arranged in rows (Siemensma, 2019). 
Jassey et al. (2014) showed that small testate amoebae were more abundant in rich and extremely rich fens than in poor and moderately rich fens. This study also showed that species with a central aperture such as Arcella discoides Ehrenberg 1843 and $M$. patella, as well as idiosomic species such as P. irregularis and Tracheleuglypha dentata (Vejdovsky 1882), dominate communities extending toward the richer part of the gradient. In a study of subalpine peatlands covering the full bog to rich fen gradient, the species richness of testate amoebae was highest in calcium-rich and extremely calcium-rich fens when compared to calcium-poor fens and bogs (Lamentowicz et al., 2010). New Zealand peatlands in contrast, are characterized by higher relative abundances of small taxa in areas at the acidic end of the $\mathrm{pH}$ gradient $(\mathrm{pH} 4.0-4.5)$ as well as in wetter habitats (DWT -10 to $20 \mathrm{~cm}$ ), as compared to higher $\mathrm{pH}$ (5.0-5.5) and drier habitats (DWT 25-50 cm; McKeown et al., 2019). These results clearly indicate the need for more detailed studies on determining the nature of testate amoebaenvironment relationships in fens.

\section{Tropical Peatlands}

Tropical peatlands, which are mainly located in lowlands (Page and Baird, 2016), differ from temperate, boreal and montane peatlands in their hydrology, vegetation, nutrient distribution, oxygenation, as well as by these environments being characterized by generally higher temperatures (Lawson et al., 2014; University of Leeds Peat Club et al., 2017). Unfortunately, in comparison to high- and mid-latitude peatlands, there have been relatively few studies carried out on assessing the diversity and ecology of testate amoebae from tropical peatlands. Since the taxonomic composition in tropical peatlands may vary due to biogeographic limitations, there is a need to carry out additional studies on the communities composition, species richness, and functional traits for each region separately, in order to detect similarities or differences in the ecological constraints characterizing similar species, as well as for geographically restricted ones.

For example, in a study assessing the ecological influence of changes in hydrology in tropical montane rainforests along an elevation gradient, testate amoeba species richness did not respond to a $64 \%$ reduction of precipitation, but at the same times population density decreased by $91 \%$ (Krashevska et al., 2012). In contrast, in the subarctic it was observed that simulated extreme rainfall was correlated with a reduction in the mean abundance and species richness of testate amoebae (Tsyganov et al., 2013). Thus, although all testate amoebae need water to be active (i.e., to move, feed and reproduce), different taxa in different regions and ecosystems may have different tolerances related to soil water availability. It is therefore required that the environmental conditions influencing the morphological or functional traits characterizing the most representative taxa in the community should be emphasized.

Such traits as testate amoeba test size have been shown to be related to hydrology and temperature in temperate zones (Lousier, 1974; Bobrov et al., 1999; Mitchell et al., 2008a). This correlation is also true for the taxa frequently found in tropical systems (e.g., Trigonopyxis arcula s.l. Penard 1912, Hyalosphenia subflava s.l. Cash and Hopkinson 1909). For instance, in both a tropical montane rainforest of Ecuador, and in lowland tropical rainforests and peatlands of Indonesia, over 40 different morphotypes of $T$. arcula were observed, with test size varying from 60 to $210 \mu \mathrm{m}$ (Krashevska et al., 2007, 2010, 2016; Schulz et al., 2018). It was shown for Trigonopyxis that test size, increased on average by $20 \mu \mathrm{m}$, with decreasing temperature (from 19 to $9^{\circ} \mathrm{C}$ mean annual temperature) and increasing precipitation (from 2200 to $4500 \mathrm{~mm}$ year $^{-1}$; Schulz et al., 2018). Similarly, the test size of $H$. subflava in peatlands of Indonesia, Peru and Panama ranged from 35 to $140 \mu \mathrm{m}$, and different test sizes correlated differently with water table depth in both modern and paleo samples of peatlands (Swindles et al., 2014, 2016, 2018; Biagioni et al., 2015; Krashevska et al., 2020). Therefore, $H$. subflava test size changes from small to large can be considered as an indicator trait of frequent hydrological changes from drier to wetter conditions in tropical peatlands, whereas in highand mid-latitude peatlands this species is considered as an unambiguous indicator of dry conditions (Charman et al., 2000).

Moreover, test composition has been shown to be a useful trait reflecting anthropogenic environmental changes in tropical lowlands. For example, the decrease in the abundance of testate amoebae with siliceous tests in oil palm plantations compared to that in rainforest environments has been hypothesized to indicate the influence of anthropogenic desilication on community structure. Further, species with siliceous tests showed a negative correlation with soil temperature and a positive correlation with water content and the amount of litter (Krashevska et al., 2016).

Similar to traits connected with the test, the trophic status (mixotrophy vs. heterotrophy) can be a potentially good indicator trait of habitat openness (Payne et al., 2016; Herbert et al., 2019), yet a less frequent studied one, especially in the tropics (Krashevska et al., 2012). A mixotroph, such as H. papilio, widespread in the Northern Hemisphere peatlands, is absent or very rarely found in tropical regions, underscoring the need for experimental studies to identify representative mixotrophs in the tropics. However, mixotrophic species within the genera Placocista and Archerella, as well as some species of the genus Heleopera, and heterotrophic species of Assulina and Euglypha, often found in the tropics, have been observed to respond to change in light intensity, making them potentially suitable indicators of plant habitat openness in tropical regions (Schönborn, 1965; Searles et al., 2001; Robson et al., 2005; Krashevska et al., 2012; Payne et al., 2016).

\section{Lacustrine Environments}

The principal testate amoebae studied in lacustrine environments are Arcellinida. Arcellinidans play a key role in aquatic ecosystems where they exert considerable predatory pressure on bacteria and smaller eukaryotic microbes and represent an important intermediary food web component (Beyens and Meisterfeld, 2001; Patterson and Kumar, 2002; Anderson, 2012). Tests typically range in size from 5 to $500 \mu \mathrm{m}$, and are comprised primarily of high-preservation potential agglutinated material (e.g., mineral grains and diatom frustules with autogenous cement), although species characterized by idiosomic tests are also observed (Medioli and Scott, 1988). 
Arcellinidans are found in lacustrine environments from the equator to poles, although they are most abundant in temperate environments where they are often present in great abundances (500-3000 specimens per ml; Patterson and Kumar, 2002; Patterson et al., 2015).

Lakes are comprised of lentic ecosystems ranging in size from ponds to thousands of square kilometers that can be subdivided into a myriad of habitats influenced by numerous climatic and physio-chemical constraints (e.g., open water, shallow littoral habitats with macrophytes, varying trophic status, thermoclines, $\mathrm{pH}$ ). Arcellinida are mostly restricted to benthic habitats, but species with at least a partial planktic habit have been documented (Schönborn, 1962; Medioli et al., 1987; Yu et al., 2014). A large body of research has been produced that has documented the complex community responses of Arcellinida in these subenvironments, and due to the large number of environmental variables typical of lacustrine systems considerable intra-lake and inter-lake assemblage variability has been observed (Patterson, 1996; Roe et al., 2010; Nasser et al., 2016, 2020a; Steele et al., 2018; Cockburn et al., 2020). There has been considerable taxonomic confusion within the Arcellinida due to a historical proliferation of new species as a result of the considerable morphological variability observed within some taxa, and the common practice of describing new species within a regional context with little consideration of research elsewhere, (e.g., Medioli et al., 1990; Wanner and Meisterfeld, 1994; Bobrov et al., 1999; Wanner, 1999; Charman et al., 2000). For Arcellinida found in lacustrine settings, Medioli and Scott (1983) proposed a possible solution by suggesting that species be considered as widely variable groups that collectively, for any given wild population, accommodate $75 \%$ or more of the morphological variability within the entire population. Through the late $1980 \mathrm{~s}$ and 1990s this approach was refined with the establishment of an informal infrasubspecific nomenclature, which in the lacustrine research community became known as 'strains' (e.g., Medioli et al., 1987; Asioli et al., 1996). The 'strain' approach came out of the recognition that the morphology of certain specimen, not necessarily linked to specific taxa, could be associated with specific environmental stressors, which during multivariate statistical analysis permitted the recognition of more subtle environmental subdivision than would be otherwise possible (Patterson, 1996; Patterson and Kumar, 2002).

The increase in the number of functional taxonomic units afforded by deployment of the 'strain' concept has permitted lacustrine researchers to more effectively explore the spatiotemporal effects of various sedimentological, geochemical, and organic variables, as well as the influence of lacustrine parameters on community structure and dynamics (Collins et al., 1990; Patterson, 1996; Reinhardt et al., 1998; Kumar and Patterson, 2000; Escobar et al., 2008; Neville et al., 2010; Roe et al., 2010; Nasser et al., 2016; Gavel et al., 2018; Steele et al., 2018; Cockburn et al., 2020). For instance, many studies have confirmed the sensitivity of arcellinidan communities to variability in $\mathrm{pH}$ (e.g., Asioli et al., 1996; Kumar and Patterson, 2000; Escobar et al., 2008; Neville et al., 2010; Patterson et al., 2013). Changes in the trophic state of lakes have also been shown to profoundly impact arcellinidan distribution (e.g., Reinhardt et al., 2005; Roe et al., 2010; Patterson et al., 2012; Gavel et al., 2018; Prentice et al., 2018). Several researchers have also linked community dynamics to changes in lake salinity (e.g., Roe et al., 2010; Roe and Patterson, 2014; Cockburn et al., 2020). The recognition that arcellinidan species and 'strains' are sensitive to industrial contamination has attracted particularly close attention. For example, studies from Italy (Asioli et al., 1996) and Canada (Patterson, 1996; Reinhardt et al., 1998) were amongst the first to demonstrate the sensitivity of Arcellinida populations to the impact of mine-induced metal contamination, albeit in a semi-quantitative manner. The advent of more sophisticated multivariate statistical techniques resulted in the quantification of the spatio-temporal relationship between Arcellinida assemblages and mine-derived contaminants (Kauppila et al., 2006; Kihlman and Kauppila, 2009, 2010, 2012; Patterson et al., 2013; Nasser et al., 2016; Gavel et al., 2018; Cockburn et al., 2020; Nasser et al., 2020a,b). The great diversity and variety in arcellinidan lacustrine research, coupled with the use of multivariate statistics, has not only permitted identification of the environmental controls on arcellinidan assemblage distribution, but also established better links between functional 'strain' traits and specific environments.

In spite of the significant advances in understanding species/'strain'-environment relationships, very few studies have focused on the characterization of specific traits in lake environments (e.g., Macumber et al., 2014, 2020; Steele et al., 2020). The lack of studies may be the result a number of factors, including:

(1) Challenges associated with the counting medium. In contrast to the analysis of peatland testate amoeba, which are counted under cover-slips using light microscopy, the size range of lake Arcellinida examined are typically in the 37-200 $\mu \mathrm{m}$ range and enumerated in vitro in Petri dishes using relatively low power stereomicroscopy, which hinders the measurement of some traits (e.g., process length and aperture size; Patterson and Kumar, 2002; Wall et al., 2010a,b). There are also complications relating to the $3 \mathrm{D}$ morphology of specimens examined in Petri dishes vs. the compressed 2D morphology of specimens observed under coverslips.

(2) Taxonomic challenges. As outlined above, phenotypic plasticity, especially within the difflugiids (Medioli and Scott, 1983; Wanner and Meisterfeld, 1994; Wanner, 1999), has led to challenges in determining the relationship between morphological characteristics and environmental drivers, or other factors (e.g., stochastic processes; cf. Medioli et al., 1987; Prentice et al., 2018; Macumber et al., 2020).

(3) Taphonomic challenges. Although the relative abundance of live vs. dead specimens are documented in applied lacustrine research, the emphasis is on providing an overview of average annual conditions so total specimen counts, which include both live and dead specimens, are analyzed, with little consideration of seasonal changes in standing crop and associated taphonomic processes (e.g., Nasser et al., 2020a,b). The 
attraction of this approach is that average environmental conditions are measured, which would otherwise require multiple expensive geochemical analyses to replicate. Two studies, one carried out as part of a seasonal assessment of the effectiveness of an oil sands reclamation project in northern Alberta, Canada (Neville et al., 2010), and a second that looked at the impact of seasonality on a lake on the Ganga-Yamura Plains of North India (Farooqui et al., 2012), both demonstrated that there are significant seasonal changes in arcellinidan standing crop that can be directly related to taphonomic processes. These studies demonstrated the complexity of the response of Arcellinida to a range of environmental drivers, but also present the promise that the group can be used as a high temporal resolution biomonitoring tool.

Notwithstanding these issues, there has been a recognition of the significance of the role of test morphology between specific environments and across gradients. For example, Velho et al. (2003) and Lansac-Tôha et al. (2014) classified taxa according to dominant test morphology (e.g., hemispherial, flattened, spherical and elongated forms) in floodplain lakes in southern Brazil and linked this to habitat types and hydrological flow regimes. Macumber et al. (this issue) applied geometric morphometrics (Zelditch et al., 2012) to examine morphological responses across a temporal gradient of nutrient enrichment in a shallow Scottish lake (dominant test morphology, aperture size; biovolume) and compared this to species-based approaches. A further earlier study focused on an autecological approach to quantify taxonomic divisions between two strains of Difflugia protaeiformis LeClerc in Lamarck 1816, in relation to a wide array of environmental proxy data from urban lakes (Macumber et al., 2014). The more time-consuming characterization of traits in lake Arcellinida, in particular quantification of subtle changes in morphology (e.g., tapering of the neck, nature of complex basal processes, apertural characteristics), which are not readily captured by simple quantitative 2-dimensional metrics, has limited the application of traits-based analysis in lake Arcellinida. However, the introduction of new technologies may lead to a significant reduction in analytical time. A novel experiment carried out by Steele et al. (2020), demonstrated that a Flowcam flow cytometer used in conjunction with machine learning software could not only significantly decrease specimen enumeration time, but using a library of $>40$ morphometric properties, was able to group tests into morpho-groups that could be used to effectively identify distinct limnological habitats.

\section{Soil and Other Wetland Habitats}

Studies on the functional ecology of testate amoebae were first developed for soils with the test typology developed by Louis Bonnet (Bonnet, 1964, 1975). Bonnet developed a classification of testate amoebae communities based on a phytosociological hierarchical classification scheme and established correlations between soil and humus developmental stages and testate amoeba communities (Bonnet, 1961b). Based on this, he identified indicators for different soil types and also compiled extensive lists of ecological preferences for soil testate amoebae (Bonnet, 1976a, 1984, 1985, 1986, 1988, 1989, 1991a,b, 1992). The ecology of testate amoebae was also studied in agro-ecosystems and the impact of farming practices and pesticides on community structure was assessed (Foissner, 1987, 1997, 1999; Heger et al., 2012). These studies generally showed a negative impact of intensive farming on the diversity and abundance of testate amoebae. However, only a small number of studies have investigated functional traits of testate amoebae in soils, and these included terrestrial soils (Wanner and Xylander, 2005), various aquatic substrate types in the arctic tundra (Mattheeussen et al., 2005; Beyens et al., 2009), and floodplain soils (Fournier et al., 2012). All these studies included the phylogenetic grouping proposed by Bonnet (1976b) (i.e., the lobose vs. filose testate amoebae L/F index, see section "Testate Amoebae Traits and Ecological Roles Before "Functional Traits"”).

Studies carried out in both high Arctic and sandy inland dune settings revealed similar recruitment patterns despite contrasting environmental conditions/filters (Mattheeussen et al., 2005; Wanner and Xylander, 2005; Beyens et al., 2009). In these habitats filose species typically fulfilled the role of rapid generalist colonizers, whereas lobose amoebae characterized more mature stable habitats. The lobose species that became part of these ecosystems during later successional stages did not outcompete and replace the earlier colonizers, but instead enlarged the existing microbial loop (Wanner and Xylander, 2005). The ready addition of lobose testate amoebae to these environments is in part related to these taxa being more resistant to warmer soil conditions, and associated desiccation that is better than filose species (Beyens et al., 2009). These findings confirmed previous assumptions that a high $\mathrm{L} / \mathrm{F}$ index is characteristic of more stable and/or more developed habitats (Bonnet, 1976b).

The first ecological study of testate amoebae ever carried out in floodplain soils used not only functional traits, but also functional indices to characterize the testate amoebae communities, including: functional richness, divergence, dispersion, and evenness (Fournier et al., 2012). The results of this research revealed that although these environmental filters were significant in shaping the patterns of testate amoeba community structure, the main variable influencing amoeba diversity was soil moisture. Among functional traits analyzed, test-related traits, particularly compression and biovolume, were the most responsive to environmental changes.

The following studies that focused on the neotropical floodplains confirmed the significant role of environmental filters in the shaping of testate amoeba communities (Arrieira et al., 2015). Especially moisture was a variable to which testate amoebae species richness and abundance were significantly correlated (Arrieira et al., 2017). Among functional traits analyzed, morphological variability and test-related traits such as test composition, test height and breadth, and presence of gas vacuoles that support movement in the water column (Ogden, 1991), were the most responsive to environmental changes (Arrieira et al., 2016; Schwind et al., 2016a,b).

\section{Marginal Marine Environments}

Salt marsh testate amoebae are present both in brackish and intertidal zones next to diatoms and foraminifera (Riveiros et al., 
2007; Barnett et al., 2017b), and have been shown to be important sea-level indicators (Patterson et al., 1985; Charman et al., 1998; Roe et al., 2002; Barnett et al., 2016, 2017a,b). Testate amoebae are strongly correlated with elevation and flooding duration and frequency in salt marsh environments (Charman et al., 1998; Roe et al., 2002). When it comes to distribution of salt marsh testate amoebae, especially important factors are salinity, particle size and organic matter content that vary locally (Charman et al., 2002; Ooms et al., 2011). Idiosomic tests typically dominate in high saltmarsh habitats above the mean high water mark and in supra-tidal settings, while in mid marsh settings low diversity agglutinating assemblages are observed (Gehrels et al., 2001).

Another very diverse group of testate amoebae are the interstitial testate amoebae typical of sandy saline freshwater and marine habitats. Because of their relatively late discovery and scarce subsequent investigation, little is known about their adaptive strategies for inhabiting marine and psammal supralittoral marine environments (Golemansky, 1969, 1978, 1998; Chardez, 1971, 1980; Golemansky and Ogden, 1980). The most characteristic morphological feature characterizing many interstitial testate amoeba taxa is the presence of a collar, which can be either small (e.g., Centropyxiella lucida Golemansky 1971) or very large, having a similar diameter as the maximum breadth of the test [e.g., Messemvriella filosa Golemansky, 1973, Pseudocorythion acutum Wailes 1927, Ogdeniella elegans (Golemansky 1970), O. maxima (Golemansky 1970), Chardezia caudata Golemansky 1970, Corythionella sp., Micramphora pontica Valkanov 1970] (Golemansky and Todorov, 2004, 2006, 2007). The molecular variability within this group of species is unknown (Todorov et al., 2009; Heger et al., 2011). As a result, the inferred general taxonomic relationships between these species are primarily based on species morphology (Golemansky, 2008).

\section{DESCRIPTION OF KEY TESTATE AMOEBA TRAITS FOR PALEOECOLOGY}

Although testate amoeba traits have only recently been used in paleoecology, several functional traits have been found to be particularly useful for paleoecological reconstructions, while others have yet to be tested in long-term studies (Table 1).

\section{Key Testate Amoeba Traits for Paleoecological Studies of Peatlands} Mixotrophy

In both observational and experimental studies mixotrophic testate amoebae (e.g., H. papilio, A. flavum, Amphitrema wrightianum Archer, 1869, Heleopera sphagni Leidy, 1874, Placocista spinosa Penard, 1899) have been found to be useful for analysis of both wet and open, highly acidic Sphagnumdominated peatlands (i.e., high light intensity, landscape openness and high water table; Schönborn, 1965; Lamentowicz and Mitchell, 2005; Mazei and Tsyganov, 2006). In these studies the appearance of mixotrophic taxa in a peat sequence has been interpreted to be indicative of either development of an opening of the landscape due to forest decline or deforestation, especially in small sites surrounded by forest cover.
When peatlands develop over a siliceous impermeable bedrock following deforestation there is often a rise in the peatland water table due to increased surface runoff (Warner et al., 1989; Sillasoo et al., 2007). Such changes generally lead to higher abundances of mixotrophs due to both the higher water table changes, and an increase in solar radiation resulting from the disappearance of the forest canopy. The opposite case (i.e., the disappearance of mixotrophs in peat profiles) may indicate a lowering of the water table and/or tree encroachment and afforestation of the peatland. Such information is highly relevant for the interpretation of long-term changes in testate amoeba communities and has implications for land-use management (Davis and Wilkinson, 2004). In this way, testate amoebae provide not only water table depth changes information, but can also enhance our understanding of other paleoecological processes that took place in the studied site in the past.

Several previous paleoecological studies have examined long-term changes in the abundance of mixotrophic testate amoeba taxa in peat profiles, with the interpretation of the micropaleontological data being supported by multi-proxy biotic and abiotic evidence. This body of research includes research from Polish Sphagnum-dominated peatlands where it was determined that increased human peatland disturbance (e.g., deforestation, prescribed burns, peat extraction, establishment of drainage ditches) led to water table lowering; the effect on testate amoeba communities resulted in a rapid decline of mixotrophs (Lamentowicz et al., 2009b; Marcisz et al., 2015, 2016, 2019; Kołaczek et al., 2018). When no evidence of direct human peatland disturbance was observed, stratigraphic sections from an open bog were characterized by continuous Sphagnum growth and an associated stable hydrology, as indicated by the regular presence of mixotrophs within observed testate amoeba communities (Marcisz et al., 2020). As mixotrophs are the first functional group to respond to direct disturbances connected with either water table lowering or increased shading, it can be assumed that a loss of this trait from species in the testate amoeba community is an indicator of both water table lowering and peatland openness. A recent study by Zhang et al. (2020b) investigated peat cores from boreal bogs in Finland and compared paleoecological data with instrumental meteorological measurements. The authors confirmed that drying and associated lower carbon accumulation rates in the peatland were related to significant loss of mixotrophic testate amoebae (Zhang et al., 2020b). In another study, van Bellen et al. (2018) showed that the establishment of permafrost conditions in an ombrotrophic peatland in Canada coincided with the disappearance of mixotrophic testate amoebae. These researchers interpreted the of loss mixotrophs to be due to a significant reduction in peat accumulation, in conjunction with an input of dust on the surface of the peatland, which would impact food sources, giving heterotrophic testate amoebae a competitive advantage (van Bellen et al., 2018). These findings indicate that mixotrophs can easily outcompete heterotrophs under acidic peatland conditions by relying on photosynthetic symbionts for supplemental nutrition when prey abundance is scarce, whereas under nutrient-rich conditions heterotrophs have the competitive edge. The results of these 
studies indicate that tallying changes in the abundance of mixotrophic testate amoebae alone, or by comparing the ratio between mixotrophs and heterotrophs over time, provides a simple index of environmental changes integrating hydrology, landscape openness and carbon accumulation potential. These results provide further confirmation of just how interconnected functional traits and environmental drivers are, highlighting their potential in paleoecological reconstructions.

\section{Position of Test Aperture}

Louis Bonnet first demonstrated the clear relationship between apertural position and soil moisture conditions (see section "Soil and Other Wetland Habitats"). Apertural position is believed to have evolved as an adaptation of testate amoebae to variable soil moisture conditions (Lahr et al., 2019), and has been strongly correlated to both modern-day and reconstructed water table depths (Lamentowicz et al., 2015; Marcisz et al., 2016). Hydrological instability and the drying of peatlands was shown to lead to an increase in the abundance of testate amoebae with small plagiostomic apertures, which during dry seasons may prevent desiccation, and a decline in taxa with axial or acrostomic apertures (Lamentowicz et al., 2015; Marcisz et al., 2016). Lamentowicz et al. (2007, 2009a) showed that increased soil erosion after deforestation caused a Sphagnum bog to shift to a fen; a process which led to an increase in the relative abundance of the plagiostomic species Centropyxis aerophila Deflandre 1929 highlighting its possible adaptation to disturbed sandy habitats (Figure 1). Furthermore, a study covering the whole bog-tofen gradient shows that hidden apertures are not only linked to lower water tables, but are also associated to higher mineral matter input (Lamentowicz et al., 2009a). These promising results illustrate the need for more studies covering the entire rich fen to bog gradient (see section "Fens").

\section{Test and Aperture Size}

Several observations and experiments have shown that the size of testate amoeba tests may be controlled by hydrological conditions, which suggests that species with small tests are probably better adapted to survive under dry conditions (see McKeown et al., 2019). Therefore, in peat cores, an observed shift in the dominant test size of testate amoebae may indicate a change in hydrology (or other relevant environmental factor), as confirmed by two paleoecological studies. An analysis of four peat records from North America and Europe revealed the coexistence of small and large testate amoebae during high water tables phases, but the abundance of larger species decreased after the water table declined (Fournier et al., 2015). A similar pattern was observed in two Central European peatlands, where the communities were dominated by small testate amoebae following direct human-induced impacts (Marcisz et al., 2016). Smaller testate amoeba species are characterized by smaller apertures, which may reduce desiccation, but because the tests are smaller in general makes them more prone to drying out. In terms of a peatland trophic status, a shift to smaller species expressed by a decrease in aperture size, body length and biovolume has also been linked to decreasing $\mathrm{pH}$ in Sphagnum-dominated peatland (Gałka et al., 2017). These observations indicate that interpreting the morphological adaptation of species to different microhabitats present on the surface of bogs can be complicated (i.e., hummock and hollows structure).

\section{Test Type/Construction}

Testate amoebae build their tests from various available material. The most commonly observed test types are those constructing: idiosomic tests produced using biosilica or calcite plates; organiccoated idiosomic tests; proteinaceous tests; and xenosomic (agglutinated) tests comprised of recycled organic or mineral material (Mitchell et al., 2008b). Several paleoecological studies have investigated whether changes in erosion processes or an increase in dust deposition translates into changes in the testate amoeba community structure. Increased input of mineral matter should stimulate the growth of species building idiosomic and xenosomic tests. Therefore, an increased abundance of these species in the stratigraphic record could indicate significant environmental change. Lamentowicz et al. (2009a) showed how vast deforestations led to increased catchment erosion, which increased the input of nutrients into the peatland, and led to a rapid increase in $\mathrm{pH}$ values from acidic to alkaline. This ecological shift caused a rapid decrease of testate amoebae possessing proteinaceous and organic-coated tests, and was directly linked to the subsequent appearance and dominance of C. aerophila and Phryganella acropodia (Hertwig et Lesser 1874), two species characterized by a xenosomic test (Lamentowicz et al., 2009a). A similar shift was described in another study based on a raised bog, where deforestation and severe disturbance by fire caused a temporal decrease in Sphagnum and an encroachment of vascular vegetation (Marcisz et al., 2019). In response to this environmental shift, testate amoebae with proteinaceous tests decreased in abundance in favor of those constructing tests utilizing xenosomes and organic-coated idiosomes (Marcisz et al., 2019).

Studies on dust deposition have significantly contributed to our understanding of testate amoeba trait variability over time. High levels of atmospheric dust deposition derived from southern Poland anthropogenic sources during the 1980s significantly impacted Sphagnum bog microbial communities (Fiałkiewicz-Kozieł et al., 2015). Testate amoebae with proteinaceous tests were observed to decrease and communities became dominated by xenosomic $C$. aerophila and $P$. acropodia. In addition, $\mathrm{Al}, \mathrm{Ti}, \mathrm{Cr}, \mathrm{Ni}$, and $\mathrm{Cu}$ concentrations were found to be highly correlated with aperture position/body size ratio and aperture position (Fiałkiewicz-Kozieł et al., 2015). In contrast, van Bellen et al. (2018) did not find any relationship between dust flux and the relative abundance of agglutinating testate amoebae. They hypothesized that the mineral particles typically being transported to mires were too large for testate amoeba to incorporate into their tests (van Bellen et al., 2018). In contrast, another study found that testate amoebae incorporated volcanic dust into their tests based solely on particle size with little or no selection by mineral type (Delaine et al., 2016). These results suggest that changes in test type and construction can therefore be used as an additional anthropogenic indicator, providing environmental information related to deforestation, human-induced changes in trophic status, dust deposition from 
anthropogenic industrial sources, as well as influences related to natural events (e.g., volcanic eruptions). As generation times of testate amoebae are short, their response to external factors influencing grain size input is much faster than that of vegetation (be it local bryophytes and vascular plants, or the surrounding upland vegetation), adding to their value as indicators of both anthropogenic and natural grain-size related inputs.

\section{Key Testate Amoeba Traits for Paleoecological Studies of Lakes} Test Type/Construction

Lake testate amoeba communities are overwhelmingly dominated by agglutinated species, although proteinaceous forms (notably Arcella species) are commonly observed. Arcella vulgaris Ehrenberg, 1830, for example, is a key component of 'stressed' assemblages associated with low oxygen and/or low $\mathrm{pH}$ conditions, and sediments strongly impacted by contaminants (e.g., heavy metals, winter de-icing salts; Dalby et al., 2000; Neville et al., 2011; Roe and Patterson, 2014; Figure 3). Idiosomic species, in contrast, typically form a minor assemblage constituent and are sometimes absent from paleolimnological records. This may partly reflect preparation techniques that result in the removal of smaller tests (notably the use of coarse sieve meshes to remove mineral content, but see Wall et al., 2010a,b), or preservation issues (Roe and Patterson, 2006). Some lake taxa exhibit a composite wall structure that may reflect changes in the availability of mineral material for test construction. Cucurbitella tricuspis (Carter, 1856), for example, displays complex changes in test wall composition related to life-cycle stage, switching from a dominance of xenosomic to idiosomic test construction between benthic and pelagic phases (Schönborn, 1962; Medioli et al., 1987; Meisterfeld, 1991). This transition is thought to be controlled by the ingestion of lipids from filamentous green algae, which aids buoyancy (Schönborn, 1962; Medioli et al., 1987). Given the significance of this species as an eutrophic indicator taxon, understanding the temporal controls on test composition (along with any associated changes in morphology) will continue to be important in paleolimnological studies (Prentice, 2019).

\section{Test Morphology}

Lake Arcellinida display enormous variability in test morphology, and there has been growing interest in assessing whether this is an adaptive response to aquatic conditions. Velho et al. (2003), for example, noted that in the floodplain environments of the Upper Paraná River, Brazil, species with a flattened (compressed) or an elongated test were most abundant in lotic (moving water) habitats associated with higher values of dissolved oxygen and $\mathrm{pH}$, while spherical and hemispherical taxa were most abundant in lentic (still water) environments with greater concentrations of chlorophyll $a$. In this study and others, compressed morphologies, along with the presence of gas vacuoles (as observed, for example, in Arcella species) were hypothesized to minimize resistance to water, allowing floating and movement in the water column (Ogden, 1991; Velho et al., 2003; Arrieira et al., 2015, 2016).

Many shape-related observations have been made in macrophyte-enriched lakes. Lansac-Tôha et al. (2014) observed higher frequencies of spherical and elongated taxa in floodplain lakes rich in aquatic macrophytes, and a greater abundance of elongate species in sedimentary floodplain habitats. Macumber et al. (this issue) similarly noted that spherical and ovoid shape groups increased in sediments impacted by cultural eutrophication in a well-studied core from a large, shallow Scottish lake, while elongated taxa were dominant in sediments with oligo- to mesotrophic plant macrofossil assemblages (Salgado et al., 2010). Intra-species variations in morphology were also observed as the nutrient status of the lake changed. The functional diversity of floodplain testate amoeba communities in the Upper Paraná River, Brazil was also reported to be controlled by nutrient dynamics (Arrieira et al., 2015). These studies hold considerable promise, although it is likely that in macrophyte-dominated lake settings, testate amoeba communities are influenced by multiple drivers, including light and oxygen availability, substrate characteristics and the character of microbial food webs, as well as nutrient fluxes (Wiik et al., 2015; Prentice et al., 2018; Roe et al., unpublished data). Future work to elucidate traits in paleolimnological records must consider these complex, inter-related controls.

In addition to overall test morphology (i.e., test outline), the presence of basal processes (spines), or aperture-related features (e.g., serrated collars or teeth) have long been thought to play a functional role in lake Arcellinida (e.g., Penard, 1902). Spines may act to stabilize the organism during feeding or aid in the entrapment of prey (Han et al., 2008) and may provide protection against predation (Gomaa et al., 2015), while teeth may be used as a cutting tool to perforate algal membranes (Medioli et al., 1987).

\section{Test and Aperture Size}

Amongst the lake Arcellinida studies that have considered the significance of test size (or biovolume), a study of the assemblages characterizing thermokarst lakes on Richard's Island in the Canadian Arctic is noteworthy (Dallimore et al., 2000). They reported tests which were larger than those typically observed in other studies, including 'giant' specimens which were 2-3 times greater in size, and suggested that this might reflect low ambient temperatures and a short growing season. They hypothesized that the organisms might feed and grow for a period of time, reaching a large size, then wait for a few days to weeks to reproduce under optimal conditions, giving rise to exceptionally large test dimensions (Dallimore et al., 2000). Macumber et al. (this issue) also reported a decrease in centroid size (biovolume) and changes in aperture size in response to nutrient enrichment and lake level lowering in the core study in Scotland. As the aperture provides the organism's main interaction with the environment, variations in its size are likely to be adaptive (Schönborn, 1962; Medioli et al., 1987; Collins et al., 1990; Bobrov and Mazei, 2004), although further systematic analysis is required to assess this, and the relationship with other traits.

\section{Mixotrophy}

The significance of mixotrophy in lake testate amoeba communities is poorly understood. This partly reflects a lack of understanding of the distribution of algal symbionts 
in limnological taxa. Feeding strategies/mixotrophy could nevertheless be important predictors in the structure of lake communities. Penard (1902) noted that mixotrophic testate amoebae can tolerate dysoxic conditions and lack of nutrition longer than non-mixotrophic specimens and hypothesized that it was due to the presence of zoochlorellae. Interestingly, Macumber et al. (2020) have recently demonstrated that mixotrophy and morphology are related within selected Difflugiidae clades, and this may also hold phylogenetic significance.

\section{Trait-Based Transfer Function Model}

In the past transfer function models have been typically based on testate amoeba species assemblage data, which are now routinely used to reconstruct past depth-to-water table (DWT) in long-term studies worldwide (Charman, 1997; Mitchell et al., 1999; Booth, 2002; Payne and Mitchell, 2007; Lamentowicz et al., 2008; Amesbury et al., 2016). A novel trait-based transfer function was recently developed by van Bellen et al. (2017) using a previously published training set (van Bellen et al., 2014), and including new measurements of several functional traits: test biovolume and compression, aperture size and position, mixotrophy, phylogenetic group, and mineral matter presence. This approach made it possible to include traits of all observed taxa, including rare ones, which is unusual in most speciesbased transfer function models, where rare taxa are excluded (van Bellen et al., 2017). Both the species-based and trait-based DWT reconstructions provided similar reconstructions, confirming the relevance of the trait-based approach in paleoecological reconstructions. In particular, trait-based transfer functions can be useful in regions where classical transfer function models are absent, or when an existing training set does not include a large number of taxa.

\section{CONCLUSION, KNOWLEDGE GAPS AND PERSPECTIVES FOR THE USE OF TESTATE AMOEBA TRAITS IN PALEOECOLOGY}

The development of testate amoeba functional traits as an area of active investigation has opened novel research avenues by providing a powerful tool for future ecological and paleoecological research. Their application can bridge long-term (paleoecological) and short-term (observational and experimental) studies addressing various aspects of not only testate amoebae ecology, but also microbial functionality and related ecosystem processes from all ecosystems where testate amoebae occur. Trait analysis can deliver important additional information that can be used to enhance that gleaned from species and community data, informing sounder paleoecological inferences.

Based on the current level of knowledge, testate amoeba morphological and functional traits can specifically provide important information on regime shifts and tipping points in ecosystem functioning caused by both natural and anthropogenic processes (Domínguez-García et al., 2019; Lamentowicz et al., 2019). Examples of systems where ecosystem functions and traits provide important monitoring data include:

- detection of forest decline, anthropogenic deforestation and landscape opening (mixotrophy);

- support for inferences of hydrological changes (i.e., dry shifts detection; mixotrophy, test size, aperture size and position);

- detection of increased nutrient deposition within a sedimentary basin (test type/construction);

- identification of autogenous environmental changes such as fen-to-bog transition (test and aperture size);

- identification of natural and anthropogenic dust deposition (test type/construction);

- assessment of carbon accumulation potential (mixotrophy);

- recognition of changes within microbial food web structures (proportion between mixotrophs and heterotrophs, L/F index).

Testate amoeba trait patterns observed in contrasting habitats show that functional traits can be a useful measure when comparing ecological shifts observed in different habitats and ecosystems where species composition may vary, but similar traits may be present.

Promising as this line of research has proven thus far, a trait-based approach applied to testate amoebae still requires substantial development in the research subdisciplines of paleoecology, as well as in observational and experimental ecology. The most significant knowledge gaps relate to the functional significance of specific traits related to testate amoeba communities, relevant biotic and abiotic characteristics in the environment, and ecosystem functioning. Many of these relationships can be inferred statistically (e.g., the correlation between peatland carbon accumulation rates and the relative abundance of mixotrophs; Zhang et al., 2020b).

Another important research question relates to the definition of response vs. effect traits. Distinguishing the two is not always obvious and in some cases, a trait can belong to both categories. An example of the latter is mixotrophy, which for example in peatlands, both responds to moisture and openness, and contributes to carbon sequestration.

In this review an outline of the current theoretical and empirical state of research of a functional traits approach applied to testate amoebae has been presented. Although this field of research is still in its infancy it presents great promise as an important tool in future ecological and paleoecological studies. We look forward to seeing its development in the near future!

\section{AUTHOR CONTRIBUTIONS}

KM led the study. All the authors contributed to the review with discussions, ideas, photos, diagrams, comments, and text. 


\section{FUNDING}

KM and ML were supported by the National Science Centre (Poland), grant 2015/17/B/ST10/01656. VJ acknowledges the French National Research Agency (Mixopeat; grant number ANR-17-CE01-0007). VK was financed by the Deutsche Forschungsgemeinschaft (DFG), project number 192626868-SFB 990. YM and AT were financially supported by the Russian Science Foundation (19-1400102). DS acknowledges the Swiss National Science Foundation (P2NEP3_178543). EL was funded by grants from the Spanish Government PGC2018-094660-B-I00

\section{REFERENCES}

Amesbury, M. J., Booth, R. K., Roland, T. P., Bunbury, J., Clifford, M. J., Charman, D. J., et al. (2018). Towards a Holarctic synthesis of peatland testate amoeba ecology: development of a new continental-scale palaeohydrological transfer function for North America and comparison to European data. Quat. Sci. Rev. 201, 483-500. doi: 10.1016/j.quascirev.2018.10.034

Amesbury, M. J., Swindles, G. T., Bobrov, A., Charman, D. J., Lamentowicz, M., Mallon, G., et al. (2016). Development of a new pan-European testate amoeba transfer function for reconstructing peatland palaeohydrology. Quat. Sci. Rev. 152, 132-151. doi: 10.1016/j.quascirev.2016.09.024

Anderson, O. R. (2012). The fate of organic sources of carbon in moss-rich tundra soil microbial communities: a laboratory experimental study. J. Eukaryotic Microbiol. 59, 564-570. doi: 10.1111/j.1550-7408.2012.00633.x

Andriuzzi, W. S., and Wall, D. H. (2018). Grazing and resource availability control soil nematode body size and abundance-mass relationship in semi-arid grassland. J. Anim. Ecol. 87, 1407-1417. doi: 10.1111/1365-2656. 12858

Aoki, Y., Hoshino, M., and Matsubara, T. (2007). Silica and testate amoebae in a soil under pine-oak forest. Geoderma 142, 29-35.

Arrieira, R. L., Schwind, L. T. F., Bonecker, C. C., and Lansac-Tôha, F. A. (2015). Use of functional diversity to assess determinant assembly processes of testate amoebae community. Aquat. Ecol. 49, 561-571. doi: 10.1007/s10452-0159546-Z

Arrieira, R. L., Schwind, L. T. F., Bonecker, C. C., and Lansac-Tôha, F. A. (2017). Temporal dynamics and environmental predictors on the structure of planktonic testate amoebae community in four Neotropical floodplains. J. Freshw. Ecol. 32, 35-47. doi: 10.1080/02705060.2016.1236758

Arrieira, R. L., Schwind, L. T. F., Joko, C. Y., Alves, G. M., Velho, L. F. M., and Lansac-Tôha, F. A. (2016). Relationships between environmental conditions and the morphological variability of planktonic testate amoeba in four neotropical floodplains. Eur. J. Protistol. 56, 180-190. doi: 10.1016/j.ejop.2016. 08.006

Asioli, A., Medioli, F. S., and Patterson, R. T. (1996). Thecamoebians as a tool for reconstruction of paleoenvironments in some Italian lakes in the foothills of the southern Alps (Orta, Varese and Candia). J. Foraminif. Res. 26, 248-263. doi: 10.2113 /gsjfr.26.3.248

Barnett, R. L., Bernatchez, P., Garneau, M., and Juneau, M. N. (2017a). Reconstructing late Holocene relative sea-level changes at the Magdalen Islands (Gulf of St. Lawrence, Canada) using multi-proxy analyses. J. Quat. Sci. 32, 380-395. doi: 10.1002/jqs.2931

Barnett, R. L., Garneau, M., and Bernatchez, P. (2016). Salt-marsh sea-level indicators and transfer function development for the Magdalen Islands in the Gulf of St. Lawrence, Canada. Mar. Micropaleontol. 122, 13-26. doi: 10.1016/j. marmicro.2015.11.003

Barnett, R. L., Newton, T. L., Charman, D. J., and Roland Gehrels, W. (2017b). Saltmarsh testate amoebae as precise and widespread indicators of sea-level change. Earth Sci. Rev. 164, 193-207. doi: 10.1016/j.earscirev.2016.11.002

Bartoš, E. (1940). Studien uber die moosbewohnenden Rhizopoden der Karpaten. Arch. Protistenk. 94, 93-160.
(MCIU/AEI/FEDER,UE) and the program "Atracción de Talento Investigador" from the Communidad de Madrid (2017-T1/AMB-5210).

\section{ACKNOWLEDGMENTS}

The idea for this review was inspired by lively discussions during the 9th International Symposium on Testate Amoebae (ISTA-9) that took place in Belfast, United Kingdom, in September 2018. We would like to thank Eckhard Völcker for providing the SEM photo of Pyxidicula patens.

Bartoš, E. (1946). The analysis of the microscopical fauna of the Bohemian mosses. Vestnik Zool. Sp. 10, 55-88.

Basińska, A. M., Reczuga, M. K., Gąbka, M., Stróżecki, M., Łuców, D., Samson, M., et al. (2020). Experimental warming and precipitation reduction affect the biomass of microbial communities in a Sphagnum peatland. Ecol. Indic. 112:106059. doi: 10.1016/j.ecolind.2019.106059

Berg, M. P., Kiers, E. T., Driessen, G., Van Der Hiejden, M., Kooi, B. W., Kuenen, F., et al. (2010). Adapt or disperse: understanding species persistence in a changing world. Glob. Change Biol. 16, 587-598.

Beyens, L., Ledeganck, P., Graae, B. J., and Nijs, I. (2009). Are soil biota buffered against climatic extremes? An experimental test on testate amoebae in arctic tundra (Qeqertarsuaq, West Greenland). Polar Biol. 32, 453-462. doi: 10.1007/ s00300-008-0540-y

Beyens, L., and Meisterfeld, R. (2001). "Protozoa: testate amoebae," in Tracking Environmental Change Using Lake Sediments. Volume 3: Terrestrial, Algal, and Siliceous Indicators, eds J. P. Smol, H. J. B. Birks, and W. M. Last (Dordrecht: Kluwer Academic Publishers), 121-153.

Biagioni, S., Krashevska, V., Achnopha, Y., Saad, A., Sabiham, S., and Behling, H. (2015). 8000 years of vegetation dynamics and environmental changes of a unique inland peat ecosystem of the Jambi Province in Central Sumatra, Indonesia. Palaeogeogr. Palaeoclimatol. Palaeoecol. 440, 813-829. doi: 10.1016/ j.palaeo.2015.09.048

Birks, H. J. B. (2012). "Overview of numerical methods in palaeolimnology," in Tracking Environmental Change Using Lake Sediments: Data Handling and Numerical Techniques, eds H. J. B. Birks, A. F. Lotter, S. Juggins, and J. P. Smol (Dordrecht: Springer), 19-92.

Birks, H. J. B. (2020). Reflections on the use of ecological attributes and traits in quaternary botany. Front. Ecol. Evol. 8:166. doi: 10.3389/fevo.2020.00166

Birks, H. J. B., Birks, H. H., and Ammann, B. (2016). The fourth dimension of vegetation. Science 354, 412-413. doi: 10.1126/science.aai8737

Bjorkman, A. D., Myers-Smith, I. H., Elmendorf, S. C., Normand, S., Rüger, N., Beck, P. S. A., et al. (2018). Plant functional trait change across a warming tundra biome. Nature 562, 57-62. doi: 10.1038/s41586-018-0563-7

Bles, E. J. (1929). Arcella. A study in cell physiology. Q. J. Microsc. Sci. 72, 527-648.

Blondel, J. (2003). Guilds or functional groups: does it matter? Oikos 100, 223-231. doi: 10.1034/j.1600-0706.2003.12152.x

Bobrov, A., Charman, D. J., and Warner, B. G. (1999). Ecology of testate amoebae (Protozoa: Rhizopoda) on peatlands in western Russia with special attention to niche separation in closely related taxa. Protist 150, 125-136.

Bobrov, A., and Mazei, Y. (2004). Morphological variability of testate amoebae (Rhizopoda : testacealobosea : testaceafilosea) in natural populations. Acta Protozool. 43, 133-146.

Bonk, A., Kinder, M., Enters, D., Grosjean, M., Meyer-Jacob, C., and Tylmann, W. (2016). Sedimentological and geochemical responses of Lake Żabińskie (northeastern Poland) to erosion changes during the last millennium. J. Paleolimnol. 56, 239-252. doi: 10.1007/s10933-016-9910-6

Bonnet, L. (1958). Les thécamoebiens des Bouillouses. Bull. Soc. d'Histoire Nat. Toulouse 93, 529-543.

Bonnet, L. (1959). Quelques aspects des populations Thécamoebiennes endogés. Bull. Soc. Hist. Nat. Toulouse 94, 413-428. 
Bonnet, L. (1961a). L'émission pseudopodique chez les Thécamoebiens endogés. Bull. Soc. Zool. France 86, 17-28.

Bonnet, L. (1961b). Les thécamobiens, indicateurs pédologiques, et la notion de climax. Bull. Soc. Hist. Nat. Toulouse 96, 80-86.

Bonnet, L. (1964). Le peuplement thécamobiens des sols. Rev. Écol. Biol. Sol 1, 123-408.

Bonnet, L. (1975). Types morphologiques, écologie et évolution de la thèque chez les thécamoebiens. Protistologica 11, 363-378.

Bonnet, L. (1976a). Ecologie des Thécamoebiens des sols calcaires. 1st Symp. Int. Taxon. Ecol. Thécamoeb. 26, IX-2X.

Bonnet, L. (1976b). Le peuplement thécamoebien édaphique de la Côte-d'Ivoire. Sols Région Lamto. Protistol. 12, 539-554.

Bonnet, L. (1984). Le signalement écologique des Thécamoebiens du sol. Bull. Soc. Hist. Nat. Toulouse 120, 103-110.

Bonnet, L. (1985). Le signalement écologique des Thécamoebiens du sol (deuxième partie). Bull. Soc. Hist. Nat. Toulouse 121, 7-12.

Bonnet, L. (1986). Signalement des préférences écologiques des Thécamoebiens. Bull. Lab. Biol. Quant. 2, 22-25.

Bonnet, L. (1988). Ecologie du genre Plagiopyxis (Thécamoebiens du sol). Bull. Soc. Hist. Nat. Toulouse 124, 13-21.

Bonnet, L. (1989). Données écologiques sur quelques Centropyxidae (Thécamoebiens) des sols. Bull. Soc. Hist. Nat. Toulouse 125, 7-16.

Bonnet, L. (1991a). Ecologie de quelques Euglyphidae (Thécamoebiens, Filosea) des milieux édaphiques et para édaphiques (Deuxième partie). Bull. Soc. Hist. Nat. Toulouse 127, 15-20.

Bonnet, L. (1991b). Ecologie de quelques Euglyphidae (Thécamoebiens, Filosea) des milieux édaphiques et para édaphiques (Première partie: genres Corythion et Trinema). Bull. Soc. Hist. Nat. Toulouse 127, 7-13.

Bonnet, L. (1992). Ecologie de quelques Euglyphidae (Thécamoebiens, Filosea) des milieux édaphiques et para édaphiques (Troisième partie : genre Euglypha). Bull. Soc. Hist. Nat. Toulouse 128, 11-20.

Booth, R. K. (2001). Ecology of testate amoebae (Protozoa) in two lake superior coastal wetlands: Implications for paleoecology and environmental monitoring. Wetlands 21, 564-576.

Booth, R. K. (2002). Testate amoebae as paleoindicators of surface-moisture changes on Michigan peatlands: modern ecology and hydrological calibration. J. Paleolimnol. 28, 329-348.

Booth, R. K. (2008). Testate amoebae as proxies for mean annual waiter-table depth in Sphagnum-dominated peatlands of North America. J. Quat. Sci. 23, 43-57.

Booth, R. K., Jackson, S. T., and Gray, C. E. D. (2004). Paleoecology and highresolution paleohydrology of a kettle peatland in upper Michigan. Quat. Res. $61,1-13$.

Booth, R. K., Jackson, S. T., Sousa, V. A., Sullivan, M. E., Minckley, T. A., and Clifford, M. J. (2012). Multi-decadal drought and amplified moisture variability drove rapid forest community change in a humid region. Ecology 93, 219-226.

Bovee, E. C. (1985). The lobose amebas. III. Descriptions of nine new conopodous amebas of the genus Vexillifera Schaeffer, 1926, emd. Bovee, 1951, Bovee, 1970, with comments on the genus. Arch. Protistenk. 129, 101-118.

Bregman, T. P., Sekercioglu, C. H., and Tobias, J. A. (2014). Global patterns and predictors of bird species responses to forest fragmentation: implications for ecosystem function and conservation. Biol. Conserv. 169, 372-383. doi: 10.1016/ j.biocon.2013.11.024

Bridgham, S. D., Pastor, J., Janssens, J. A., Chapin, C., and Malterer, T. J. (1996). Multiple limiting gradients in peatlands: a call for a new paradigm. Wetlands 16, 45-65. doi: 10.1007/BF03160645

Buma, B., Harvey, B. J., Gavin, D. G., Kelly, R., Loboda, T., McNeil, B. E., et al. (2019). The value of linking paleoecological and neoecological perspectives to understand spatially-explicit ecosystem resilience. Landsc. Ecol. 34, 17-33. doi: 10.1007/s10980-018-0754-5

Butterfield, B. J., Holmgren, C. A., Anderson, R. S., and Betancourt, J. L. (2019). Life history traits predict colonization and extinction lags of desert plant species since the Last Glacial Maximum. Ecology 100:e02817. doi: 10.1002/ecy.2817

Carter, H. J. (1856). Notes on the freshwater Infusoria of the island of Bombay. No. 1. Organization. Ann. Mag. Nat. Hist. Ser. 18, 221-249.

Céréghino, R., Pillar, V. D., Srivastava, D. S., de Omena, P. M., MacDonald, A. A. M., Barberis, I. M., et al. (2018). Constraints on the functional trait space of aquatic invertebrates in bromeliads. Funct. Ecol. 32, 2435-2447. doi: $10.1111 / 1365-2435.13141$
Chardez, D. (1965). Kystes de résistance chez Hyalosphenia papilio LEIDY (Rhizopoda testacea). Bull. Inst. Agron. Stat. Recherches Gembloux 33, 488-490.

Chardez, D. (1971). Etude sur les Thécamoebiens des biotopes interstitiels, psammons littoraux et zones marginales souterraines des eaux douces $(*)$. Bull. Recherches Agron. Gembloux 6, 257-268.

Chardez, D. (1980). Catalogue des Thécamoebiens du psammon supralittoral des mers et des océans. Lab. Zool. Gen. Faun. Gembloux 9.

Chardez, D., and Lambert, J. (1981). Thécamoebiens indicateurs biologiques (Protozoa Rhizopoda testacea). Bull. Recherches Agron. Gembloux 16, 181-204.

Charman, D., Hendon, D., and Woodland, W. A. (2000). The Identification of Testate Amoebae (Protozoa: Rhizopoda) in Peats. London: Quaternary Research Association.

Charman, D. J. (1997). Modelling hydrological relationships of testate amoebae (Protozoa : Rhizopoda) on new Zealand peatlands. J. R. Soc. N. Z. 27, 465-483.

Charman, D. J. (2001). Biostratigraphic and palaeoenvironmental applications of testate amoebae. Quat. Sci. Rev. 20, 1753-1764.

Charman, D. J., Roe, H. M., and Gehrels, W. R. (1998). The use of testate amoebae in studies of sea-level change: a case study from the Taf Estuary, south Wales, UK. Holocene 8, 209-218.

Charman, D. J., Roe, H. M., and Gehrels, W. R. (2002). Modern distribution of saltmarsh testate amoebae: regional variability of zonation and response to environmental variables. J. Quat. Sci. 17, 387-409.

Charman, D. J., and Warner, B. G. (1992). Relationship between Testate Amoebae (Protozoa: Rhizopoda) and microenvironmental parameters on a forested Peatland in Northeastern Ontario. Can. J. Zool. 70, 2474-2482.

Clements, F. E. (1905). Research Methods in Ecology. Nebraska, CA: The University Publishing Company.

Cockburn, C. F., Gregory, B. R. B., Nasser, N. A., and Patterson, R. T. (2020). Intra-Lake Arcellinida (Testate Lobose Amoebae) response to winter de-icing contamination in an eastern canada road-side "salt belt" lake. Microb. Ecol. 80, 366-383. doi: 10.1007/s00248-020-01513-w

Collins, E. S., McCarthy, F. M., Medioli, F. S., Scott, D. B., and Honig, C. A. (1990). "Biogeographic distribution of modern thecamoebians in a transect along the eastern North American coast," in Paleoecology, Biostratigraphy, Paleoceanography and Taxonomy of Agglutinated Foraminifera, eds M. A. Kaminski, C. Hemleben, W. Kuhnt, and D. B. Scott (Cham: Springer), 783-792.

Cornwell, W. K., Cornelissen, J. H. C., Amatangelo, K., Dorrepaal, E., Eviner, V. T., Godoy, O., et al. (2008). Plant species traits are the predominant control on litter decomposition rates within biomes worldwide. Ecol. Lett. 11, 1065-1071. doi: $10.1111 / j .1461-0248.2008 .01219 . x$

Coûteaux, M. M., and Darbyshire, J. F. (1998). Functional diversity amongst soil protozoa. Appl. Soil Ecol. 10, 229-237.

Coûteaux, M.-M., and Dévaux, J. (1983). Effet d'un enrichissement en champignons sur la dynamique d'un peuplement thécamoebien d'un humus. Rev. Ecol. Biol. Sol. 20, 519-545.

Coûteaux, M.-M., and Pussard, M. (1983). "Nature du régime alimentaire des protozoaires du sol," in New trends in soil biology. Proceedings of the VIII International Colloquium of Soil Zoology, Louvain-la-Neuve, ed. P. LeBrun (Ottignies-Louvain-la-Neuve: Universite Catholique de Louvain), 179-195.

Creevy, A. L. (2013). Microbial Diversity of a Nature Reserve: Eukaryotic Microorganisms of Mere Sands Wood in N.W. England. Ph. D. Thesis, Liverpool John Moores University, Liverpool.

Creevy, A. L., Andersen, R., Rowson, J. G., and Payne, R. J. (2018). Testate amoebae as functionally significant bioindicators in forest-to-bog restoration. Ecol. Indic. 84, 274-282. doi: 10.1016/j.ecolind.2017.08.062

Cummins, K. W. (1974). Structure and function of stream ecosystems. BioScience 24, 631-641. doi: 10.2307/1296676

Dalby, A. P., Kumar, A., Moore, J. M., and Patterson, R. T. (2000). Preliminary survey of arcellaceans (Thecamoebians) as limnological indicators in tropical lake Sentani, Irian Jaya, Indonesia. J. Foraminif. Res. 30, 135-142. doi: 10.2113/ 0300135

Dallimore, A., Schröder-Adams, C. J., and Dallimore, S. R. (2000). Holocene environmental history of thermokarst lakes on Richards Island, Northwest Territories, Canada: theocamoebians as paleolimnological indicators. J. Paleolimnol. 23, 261-283. doi: 10.1023/A:1008184522637

Davis, S. R., and Wilkinson, D. M. (2004). The conservation management value of testate amoebae as 'restoration' indicators: speculations based on two damaged raised mires in northwest England. Holocene 14, 135-143. 
de Bello, F., Lavorel, S., Díaz, S., Harrington, R., Cornelissen, J. H. C., Bardgett, R. D., et al. (2010). Towards an assessment of multiple ecosystem processes and services via functional traits. Biodiv. Conserv. 19, 2873-2893. doi: 10.1007/ s10531-010-9850-9

de Graaf, F. (1956). Studies on Rotatoria and Rhizopoda from the Netherlands. Biol. Jaarb. 23, 145-217.

de Graaf, F. (1957). The microflora and fauna of a quaking bog in the Nature Reserve 'Het Hol' near Kortenhoef in the Netherlands. Hydrobiologia 9, 210317.

Decaëns, T. (2010). Macroecological patterns in soil communities. Glob. Ecol. Biogeogr. 19, 287-302. doi: 10.1111/j.1466-8238.2009.00517.x

Deflandre, G. (1936a). Etude monographique sur le genre Nebela Leidy (Rhizopoda-Testacea). Ann. Protistol. 5, 201-286.

Deflandre, G. (1936b). Remarques sur le comportement des pseudopodes chez quelques Thécamoebiens. Ann. Protistol. 5, 65-71.

Deflandre, G. (1937). "Adaptation stationnelle et notion de l'espèce chez les thécamoebiens," in Comptes rendus du $70^{e}$ Congrès des Sociétés Savantes de Paris et des Départements. Section des sciences, (Paris: Imprimerie Nationale), 223-225.

Delaine, M., Fernández, L. D., Châtelet, E. A. D., Recourt, P., Potdevin, J.-L., Mitchell, E. A. D., et al. (2016). Cinderella's helping pigeons of the microbial world: the potential of testate amoebae for identifying cryptotephra. Eur. J. Protistol. 55, 152-164. doi: 10.1016/j.ejop.2016.05.003

Diamond, S. E., Frame, A. M., Martin, R. A., and Buckley, L. B. (2011). Species' traits predict phenological responses to climate change in butterflies. Ecology 92, 1005-1012.

Díaz, S., and Cabido, M. (2001). Vive la différence: plant functional diversity matters to ecosystem processes. Trends Ecol. Evol. 16, 646-655. doi: 10.1016/ S0169-5347(01)02283-2

Diaz, S., Hodgson, J. G., Thompson, K., Cabido, M., Cornelissen, J. H. C., Jalili, A., et al. (2004). The plant traits that drive ecosystems: evidence from three continents. J. Veg. Sci. 15, 295-304. doi: 10.1111/j.1654-1103.2004.tb0 2266.x

Domínguez-García, V., Dakos, V., and Kéfi, S. (2019). Unveiling dimensions of stability in complex ecological networks. Proc. Natl. Acad. Sci. U.S.A. 116, 25714-25720. doi: 10.1073/pnas.1904470116

Duckert, C., Blandenier, Q., Kupferschmid, F. A. L., Kosakyan, A., Mitchell, E. A. D., Lara, E., et al. (2018). En garde! Redefinition of Nebela militaris (Arcellinida, Hyalospheniidae) and erection of Alabasta gen.nov. Eur. J. Protistol. 66, 156-165. doi: 10.1016/j.ejop.2018.08.005

Escobar, J., Brenner, M., Whitmore, T. J., Kenney, W. F., and Curtis, J. H. (2008). Ecology of testate amoebae (thecamoebians) in subtropical Florida lakes. J. Paleolimnol. 40, 715-731. doi: 10.1007/s10933-008-9195-5

Farooqui, A., Kumar, A., and Swindles, G. T. (2012). Thecamoebian communities as proxies of seasonality in Lake Sadatal in the Ganga-Yamuna Plains of North India. Palaeontol. Electron. 15, 1-19. doi: 10.26879/200

Feurdean, A., Vannière, B., Finsinger, W., Warren, D., Connor, S. C., Forrest, M., et al. (2020). Fire hazard modulation by long-term dynamics in land cover and dominant forest type in eastern and central Europe. Biogeosciences 17, 1213-1230. doi: 10.5194/bg-17-1213-2020

Fiałkiewicz-Kozieł, B., Śmieja-Król, B., Ostovnaya, T. M., Frontasyeva, M., Siemińska, A., and Lamentowicz, M. (2015). Peatland microbial communities as indicators of the extreme atmospheric dust deposition. Water Air Soil Pollut. 226:97.

Foissner, W. (1987). Soil protozoa: fundamental problems. ecological significance, adaptations in ciliates and testaceans, bioindicators, and guide to literature. Prog. Protistol. 2, 69-212.

Foissner, W. (1997). Protozoa as bioindicators in agroecosystems, with emphasis on farming practices, biocides, and biodiversity. Agric. Ecosyst. Environ. 62, 93-103.

Foissner, W. (1999). Soil protozoa as bioindicators: pros and cons, methods, diversity, representative examples. Agric. Ecosyst. Environ. 74, 95-112.

Fournier, B., Coffey, E. E. D., Knaap, W. O., Fernández, L. D., Bobrov, A., and Mitchell, E. A. D. (2016). A legacy of human-induced ecosystem changes: spatial processes drive the taxonomic and functional diversities of testate amoebae in Sphagnum peatlands of the Galápagos. J. Biogeogr. 43, 533-543. doi: 10.1111/ jbi.12655
Fournier, B., Lara, E., Jassey, V. E. J., and Mitchell, E. A. D. (2015). Functional traits as a new approach for interpreting testate amoeba palaeo-records in peatlands and assessing the causes and consequences of past changes in species composition. Holocene 25, 1375-1383. doi: 10.1177/0959683615585842

Fournier, B., Malysheva, E., Mazei, Y., Moretti, M., and Mitchell, E. A. D. (2012). Toward the use of testate amoeba functional traits as indicator of floodplain restoration success. Eur. J. Soil Biol. 49, 85-91. doi: 10.1016/j.ejsobi.2011.05.008

Gąbka, M., and Lamentowicz, M. (2008). Vegetation-environment relationships in peatlands dominated by Sphagnum fallax (Klinggr.) Klinggr. in Western Poland. Folia Geobot. 43, 413-429.

Gałka, M., Tobolski, K., Lamentowicz, Ł, Ersek, V., Jassey, V. E. J., Van der Knaap, W. O., et al. (2017). Unveiling exceptional Baltic bog ecohydrology, autogenic succession and climate change during the last 2000 years in CE Europe using replicate cores, multi-proxy data and functional traits of testate amoebae. Quat. Sci. Rev. 156, 90-106. doi: 10.1016/j.quascirev.2016.11.034

Gavel, M. J., Patterson, R. T., Nasser, N. A., Galloway, J. M., Hanna, B. W., Cott, P. A., et al. (2018). What killed Frame Lake? A precautionary tale for urban planners. PeerJ 6:e4850. doi: 10.7717/peerj.4850

Gehrels, W. R., Roe, H. M., and Charman, D. J. (2001). Foraminifera, testate amoebae and diatoms as sea-level indicators in UK saltmarshes: a quantitative multiproxy approach. J. Quat. Sci. 16, 201-220.

Geisen, S., Rosengarten, J., Koller, R., Mulder, C., Urich, T., and Bonkowski, M. (2015). Pack hunting by a common soil amoeba on nematodes. Environ. Microbiol. 17, 4538-4546. doi: 10.1111/1462-2920.12949

Gilbert, D., Amblard, C., Bourdier, G., and Francez, A.-J. (1998a). The microbial loop at the surface of a peatland: structure, function, and impact of nutrient input. Microb. Ecol. 35, 83-93.

Gilbert, D., Amblard, C., Bourdier, G., and Francez, A. J. (1998b). Short-term effect of nitrogen enrichment on the microbial communities of a peatland. Hydrobiologia 374, 111-119.

Gilbert, D., Amblard, C., Bourdier, G., Francez, A.-J., and Mitchell, E. A. D. (2000). Le régime alimentaire des thécamoebiens. L'Année Biol. 39, 57-68.

Gilbert, D., and Mitchell, E. A. D. (2006). "Microbial diversity in Sphagnum peatlands," in Peatlands: Evolution and Records of Environmental and Climatic Changes, eds I. P. Martini, A. Martinez Cortizas, and W. Chesworth (Amsterdam: Elsevier), 289-320.

Gilbert, D., Mitchell, E. A. D., Amblard, C., Bourdier, G., and Francez, A. J. (2003). Population dynamics and food preferences of the testate amoeba Nebela tincta major-bohemica-collaris complex (Protozoa) in a Sphagnum peatland. Acta Protozool. 42, 99-104.

Golemansky, V. (1969). "Sur une biocenose thécamoebienne peu connue des eaux souterraines littorales des mers," in Progress in Protozoology III, (Leningrad: Nauka), 194.

Golemansky, V. (1978). Adaptations morphologiques des thécamoebiens psammobiontes du psammal supralittoral des mers. Acta Protozool. 17, $141-152$.

Golemansky, V. (1998). Interstitial testate amoebae (Rhizopoda : Arcellinida and Gromida) from the Finnish Coast of the Baltic sea and summary check list of the interstitial testate amoebae in the Baltic sea. Acta Protozool. 37, 133-137.

Golemansky, V. (2008). Origin, phylogenetic relations, and adaptations of the marine interstitial testate ameobae (Rhizopoda: Lobosea, Filosea, and Granuloreticulsea). Adv. Arachnol. Dev. Biol. 12, 87-100.

Golemansky, V., and Ogden, C. G. (1980). Shell structure of three littoral species of testate amoebae from the black sea (Rhizopodea: Protozoa). Bull. Br. Mus. Nat. Hist. 38, 1-6.

Golemansky, V., and Todorov, M. (2004). Shell morphology, biometry and distribution of some marine interstitial testate amoebae (Sarcodina: Rhizopoda). Acta Protozool. 43, 147-162.

Golemansky, V., and Todorov, M. (2006). New data to the shell ultrastructure and the biometry of the marine interstitial testate amoebae (Rhizopoda : Testaceafilosia). Acta Protozool. 45, 301-312.

Golemansky, V., and Todorov, M. (2007). Taxonomic review of the genus Centropyxiella (Rhizopoda:Filosea) with data on tis biology and geographical distribution. Acta Zool. Bulgarica 59, 227-240.

Gomaa, F., Kosakyan, A., Heger, T. J., Corsaro, D., Mitchell, E. A. D., and Lara, E. (2014). One alga to rule them all: unrelated mixotrophic testate amoebae (Amoebozoa, Rhizaria and Stramenopiles) share the same symbiont (Trebouxiophyceae). Protist 165, 161-176. doi: 10.1016/j.protis.2014.01.002 
Gomaa, F., Todorov, M., Heger, T. J., Mitchell, E. A. D., and Lara, E. (2012). SSU rRNA phylogeny of Arcellinida (Amoebozoa) reveals that the largest arcellinid genus, Difflugia Leclerc 1815, is not monophyletic. Protist 163, 389-399.

Gomaa, F., Yang, J., Mitchell, E. A. D., Zhang, W.-J., Yu, Z., Todorov, M., et al. (2015). Morphological and molecular diversification of asian endemic Difflugia tuberspinifera (Amoebozoa, Arcellinida): a case of fast morphological evolution in protists? Protist 166, 122-130. doi: 10.1016/j.protis.2014.11.004

Grospietsch, T. (1953). Die untersuchung von mooren mit hilfe der rhizopodenanalyse. Mikrokosmos 41, 219-224.

Hájek, M., Horsák, M., Hájkova, P., and Dítì, D. (2006). Habitat diversity of central European fens in relation to environmental gradients and an effort to standardise fen terminology in ecological studies. Perspect. Plant Ecol. Evol. Syst. $8,97-114$

Hájek, M., Plesková, Z., Syrovátka, V., Peterka, T., Laburdová, J., Kintrová, K., et al. (2014). Patterns in moss element concentrations in fens across species, habitats, and regions. Perspect. Plant Ecol. Evol. Syst. 16, 203-218. doi: 10.1016/j.ppees. 2014.06.003

Hajkova, P., Bojkova, J., Frankova, M., Opravilova, V., Hajek, M., Kintrova, K., et al. (2011). Disentangling the effects of water chemistry and substratum structure on moss-dwelling unicellular and multicellular micro-organisms in spring-fens. J. Limnol. 70, 54-64. doi: 10.1051/limn/2013056

Hájková, P., Horsák, M., Hájek, M., Lacina, A., Buchtová, H., and Pelánková, B. (2012). Origin and contrasting succession pathways of the Western Carpathian calcareous fens revealed by plant and mollusc macrofossils. Boreas 41, 690-706. doi: 10.1111/j.1502-3885.2012.00263.x

Hamard, S., Robroek, B. J. M., Allard, P.-M., Signarbieux, C., Zhou, S., Saesong, T., et al. (2019). Effects of sphagnum leachate on competitive sphagnum microbiome depend on species and time. Front. Microbiol. 10:2042. doi: 10. 3389/fmicb.2019.02042

Han, B.-P., Wang, T., Lin, Q.-Q., and Dumont, H. J. (2008). Carnivory and active hunting by the planktonic testate amoebae Difflugia tubersinifera. Hydrobiologia 596, 197-201.

Han, B.-P., Wang, T., Xu, L., Lin, Q. Q., and Dumont, H. J. (2011). Dynamics in space and time of four testate amoebae (Difflugia spp.) co-existing in the zooplankton of a reservoir in southern China. Eur. J. Protistol. 47, 224-230. doi: 10.1016/j.ejop.2011.04.003

Harnisch, O. (1925). Studien zur Ökologie und tiergeographie der moore. Zool. Jahrbuch 51, 1-166.

Harnisch, O. (1927). Einige Daten zur recenten und fossilen testaceen Rhizopodenfauna der Sphagnen. Arch. Hydrobiol. 18, 345-360.

Heal, O. W. (1961). The distribution of testate amoebae (Rhizopoda: Testacea) in some fens and mires in northern England. Zool. J. Linnean Soc. 44, 369-382.

Heal, O. W. (1963). Morphological variation in certain Testacea (Protozoa: Rhizopoda). Arch. Protistenkunde 106, 351-368.

Heal, O. W. (1964). Observations on the seasonal and spatial-distribution of testacea (Protozoa, Rhizopoda) in Sphagnum. J. Anim. Ecol. 33, 395-412.

Heger, T. J., Mitchell, E. A. D., and Leander, B. S. (2013). Holarctic phylogeography of the testate amoeba Hyalosphenia papilio (Amoebozoa: Arcellinida) reveals extensive genetic diversity explained more by environment than dispersal limitation. Mol. Ecol. 22, 5172-5184.

Heger, T. J., Mitchell, E. A. D., Ledeganck, P., Vincke, S., Van de Vijver, B., and Beyens, L. (2009). The curse of taxonomic uncertainty in biogeographical studies of free-living terrestrial protists: a case study of testate amoebae from Amsterdam Island. J. Biogeogr. 36, 1551-1560. doi: 10.1111/j.1365-2699.2009. 02094.x

Heger, T. J., Pawlowski, J., Lara, E., Leander, B. S., Todorov, M., Golemansky, V., et al. (2011). Comparing potential COI and SSU rDNA barcodes for assessing the diversity and phylogenetic relationships of cyphoderiid testate amoebae (Rhizaria: Euglyphida). Protist 162, 131-141.

Heger, T. J., Straub, F., and Mitchell, E. A. D. (2012). Impact of farming practices on soil diatoms and testate amoebae: a pilot study in the DOK-trial at Therwil, Switzerland. Eur. J. Soil Biol. 49, 31-36. doi: 10.1016/j.ejsobi.2011. 08.007

Heilmeier, H. (2019). Functional traits explaining plant responses to past and future climate changes. Flora 254, 1-11. doi: 10.1016/j.flora.2019.04.004

Heinis, F. (1910). Systematik und Biologie der Moosbewohnenden Rhizopoden, Rotatorien und Tardigraden der Umgebung von Basel mit Berücksichtigung der übrigen Schweiz. Arch. Hydrobiol. Plankton. 5, 17-19.
Henn, J. J., Buzzard, V., Enquist, B. J., Halbritter, A. H., Klanderud, K., Maitner, B. S., et al. (2018). Intraspecific trait variation and phenotypic plasticity mediate alpine plant species response to climate change. Front. Plant Sci. 9:1548. doi: 10.3389/fpls.2018.01548

Herbert, R. P., Peters, S. C., Nelson, D. M., and Booth, R. K. (2019). Light variability and mixotrophy: responses of testate amoeba communities and shell $\delta 13 \mathrm{C}$ values to a peatland shading experiment. Eur. J. Protistol. 67, 15-26. doi: 10. 1016/j.ejop.2018.10.005

Hunter, J. P. (1998). Paleoecology meets ecology on questions of scale. Trends Ecol. Evol. 13, 478-479.

Jassey, V. E. J., Chiapusio, G., Binet, P., Buttler, A., Laggoun-Defarge, F., Delarue, F., et al. (2013a). Above- and belowground linkages in Sphagnum peatland: climate warming affects plant-microbial interactions. Glob. Change Biol. 19, 811-823.

Jassey, V. E. J., Lamentowicz, L., Robroek, B. J. M., Gąbka, M., Rusińska, A., and Lamentowicz, M. (2014). Plant functional diversity drives niche-size-structure of dominant microbial consumers along a poor to extremely rich fen gradient. J. Ecol. 102, 1150-1162.

Jassey, V. E. J., Lamentowicz, M., Bragazza, L., Hofsommer, M. L., Mills, R. T. E., Buttler, A., et al. (2016). Loss of testate amoeba functional diversity with increasing frost intensity across a continental gradient reduces microbial activity in peatlands. Eur. J. Protistol. 55, 190-202. doi: 10.1016/j.ejop.2016.04. 007

Jassey, V. E. J., Meyer, C., Dupuy, C., Bernard, N., Mitchell, E. A. D., Toussaint, M.-L., et al. (2013b). To what extent do food preferences explain the trophic position of heterotrophic and mixotrophic microbial consumers in a sphagnum peatland? Microb. Ecol. 66, 571-580. doi: 10.1007/s00248-013-0262-8

Jassey, V. E. J., Shimano, S., Dupuy, C., Toussaint, M. L., and Gilbert, D. (2012). Characterizing the feeding habits of the testate amoebae Hyalosphenia papilio and Nebela tincta along a narrow "Fen-Bog" gradient using digestive vacuole content and 13C and 15N isotopic analyses. Protist 163, 451-464.

Jassey, V. E. J., Signarbieux, C., Hättenschwiler, S., Bragazza, L., Buttler, A., Delarue, F., et al. (2015). An unexpected role for mixotrophs in the response of peatland carbon cycling to climate warming. Sci. Rep. 5:16931. doi: 10.1038/srep16931

Jax, K. (1992). Investigations on succession and long-term dynamics of testacea assemblages (Protozoa: Rhizopoda) in the Aufwuchs of small bodies of water. Limnologica 22, 299-328.

Jennings, H. S. (1916). Heredity, variation and the results of selection in the uniparental reproduction of Difflugia corona. Genetics 1, 407-534.

Jensen, T. C., Zawiska, I., Oksman, M., Słowiński, M., Woszczyk, M., Luoto, T. P., et al. (2020). Historical human impact on productivity and biodiversity in a subalpine oligotrophic lake in Scandinavia. J. Paleolimnol. 63, 1-20. doi: 10.1007/s10933-019-00100-5

Jung, V., Violle, C., Mondy, C., Hoffmann, L., and Muller, S. (2010). Intraspecific variability and trait-based community assembly. J. Ecol. 98, 1134-1140. doi: 10.1111/j.1365-2745.2010.01687.x

Jung, W. (1936). Thekamöben ursprünglischer lebender deutscher Hochmoore. Abhandlungen Landesmus. Provinz Westfalen 7, 1-87.

Jung, W. (1942). Südchilenische thekamöben (Aus dem südchilenischen Küstengebiet, Beitrag 10.). Arch. Protisten. 95, 253-356.

Kattge, J., Bönisch, G., Díaz, S., Lavorel, S., Prentice, I. C., Leadley, P., et al. (2020). TRY plant trait database - enhanced coverage and open access. Glob. Change Biol. 26, 119-188. doi: 10.1111/gcb.14904

Kauppila, T., Kihlman, S., and Mäkinen, J. (2006). Distribution of arcellaceans (Testate Amoebae) in the sediments of a mine water impacted bay of Lake Retunen, Finland. Water Air Soil Pollut. 172, 337-358. doi: 10.1007/s11270006-9099-9

Kaustuv, R., Jablonski, D., and Valentine, J. W. (2001). Climate change, species range limits and body size in marine bivalves. Ecol. Lett. 4, 366-370.

Kihlman, S., and Kauppila, T. (2010). Tracking the aquatic impacts of a historical metal mine using lacustrine protists and diatom algae. Mine Water Environ. 29, 116-134. doi: 10.1007/s10230-009-0096-2

Kihlman, S., and Kauppila, T. (2012). Effects of mining on testate amoebae in a Finnish lake. J. Paleolimnol. 47, 1-15. doi: 10.1007/s10933-011-9541-x

Kihlman, S. M., and Kauppila, T. (2009). Mine water-induced gradients in sediment metals and arcellacean assemblages in a boreal freshwater bay (Petkellahti, Finland). J. Paleolimnol. 42, 533-550. doi: 10.1007/s10933-008-9303-6

Kleyer, M., Bekker, R. M., Knevel, I. C., Bakker, J. P., Thompson, K., Sonnenschein, M., et al. (2008). The LEDA traitbase: a database of life-history traits of the 
Northwest European flora. J. Ecol. 96, 1266-1274. doi: 10.1111/j.1365-2745. 2008.01430.x

Koenig, I., Christinat, K., d'Inverno, M., and Mitchell, E. A. D. (2018a). Impact of two hot and dry summers on the community structure and functional diversity of testate amoebae in an artificial bog, illustrating their use as bioindicators of peatland health. Mires Peat 21, 1-24. doi: 10.19189/MaP.2018.OMB.327

Koenig, I., Mulot, M., and Mitchell, E. A. D. (2018b). Taxonomic and functional traits responses of Sphagnum peatland testate amoebae to experimentally manipulated water table. Ecol. Indic. 85, 342-351. doi: 10.1016/j.ecolind.2017. 10.017

Koenig, I., Schwendener, F., Mulot, M., and Mitchell, E. A. D. (2017). Response of sphagnum testate amoebae to drainage, subsequent re-wetting and associated changes in the moss carpet - results from a three year mesocosm experiment. Acta Protozool. 56, 191-210. doi: 10.4467/16890027AP.17.017.7498

Koepcke, H.-W. (1956). Zur analyse der lebensformen. Bonn. Zool. Beitr 7, 151185.

Kołaczek, P., Karpińska-Kołaczek, M., Marcisz, K., Gałka, M., and Lamentowicz, M. (2018). Palaeohydrology and the human impact on one of the largest raised bogs complex in the Western Carpathians (Central Europe) during the last two millennia. Holocene 28, 595-608. doi: 10.1177/0959683617735587

Kosakyan, A., Heger, T. J., Leander, B. S., Todorov, M., Mitchell, E. A. D., and Lara, E. (2012). COI barcoding of nebelid testate amoebae (Amoebozoa: Arcellinida): extensive cryptic diversity and redefinition of the hyalospheniidae schultze. Protist 163, 415-434.

Kosakyan, A., Lahr, D. J. G., Mulot, M., Meisterfeld, R., Mitchell, E. A. D., and Lara, E. (2016). Phylogenetic reconstruction based on COI reshuffles the taxonomy of hyalosphenid shelled (testate) amoebae and reveals the convoluted evolution of shell plate shapes. Cladistics 32, 606-623. doi: 10.1111/cla.12167

Kosakyan, A., and Lara, E. (2019). "Using testate amoebae communities to evaluate environmental stress: a molecular biology perspective," in Encyclopedia of Environmental Health, ed. J. Nriagu (Amsterdam: Elsevier), 308-313.

Kosakyan, A., Mulot, M., Mitchell, E. A. D., and Lara, E. (2015). Environmental DNA COI barcoding for quantitative analysis of protists communities: a test using the Nebela collaris complex (Amoebozoa; Arcellinida; Hyalospheniidae). Eur. J. Protisto. 51, 311-320. doi: 10.1016/j.ejop.2015.06.005

Kraft, N. J. B., and Ackerly, D. D. (2010). Functional trait and phylogenetic tests of community assembly across spatial scales in an Amazonian forest. Ecol. Monogr. 80, 401-422. doi: 10.1890/09-1672.1

Kraft, N. J. B., Valencia, R., and Ackerly, D. D. (2008). Functional traits and nichebased tree community assembly in an Amazonian forest. Science 322, 580-582. doi: $10.1126 /$ science.1160662

Krashevska, V., Bonkowski, M., Maraun, M., and Scheu, S. (2007). Testate amoebae (protista) of an elevational gradient in the tropical mountain rain forest of Ecuador. Pedobiologia 51, 319-331.

Krashevska, V., Klarner, B., Widyastuti, R., Maraun, M., and Scheu, S. (2016). Changes in structure and functioning of protist (Testate Amoebae) communities due to conversion of lowland rainforest into rubber and oil palm plantations. PLoS One 11:e0160179. doi: 10.1371/journal.pone.0160179

Krashevska, V., Maraun, M., and Scheu, S. (2010). Micro-and macroscale changes in density and diversity of testate amoebae of tropical montane rain forests of southern ecuador. Acta Protozool. 49, 17-28.

Krashevska, V., Sandmann, D., Maraun, M., and Scheu, S. (2012). Consequences of exclusion of precipitation on microorganisms and microbial consumers in montane tropical rainforests. Oecologia 170, 1067-1076. doi: 10.1007/s00442012-2360-6

Krashevska, V., Tsyganov, A. N., Esaulov, A. S., Mazei, Y. A., Hapsari, K. A., Saad, A., et al. (2020). Testate amoeba species- and trait-based transfer functions for reconstruction of hydrological regime in tropical peatland of central Sumatra, Indonesia. Front. Ecol. Evol. Paleoecology. 8:225. doi: 10.3389/fevo.2020. 00225

Kumar, A., and Patterson, R. T. (2000). Arcellaceans (thecamoebians): new tools for monitoring long- and short-term changes in lake bottom acidity. Environ. Geol. 39, 689-697. doi: 10.1007/s002540050483

Lacourse, T. (2009). Environmental change controls postglacial forest dynamics through interspecific differences in life-history traits. Ecology 90, 2149-2160. doi: 10.1890/08-1136.1

Laggoun-Défarge, F., Mitchell, E. A. D., Gilbert, D., Disnar, J.-R., Comont, L., Warner, B., et al. (2008). Cut-over peatland regeneration assessment using organic matter and microbial indicators (bacteria and testate amoebae). J. Appl. Ecol. 45, 716-727. doi: 10.1111/j.1365-2664.2007.01436.x

Lahr, D. J. G., Kosakyan, A., Lara, E., Mitchell, E. A. D., Morais, L., PorfirioSousa, A. L., et al. (2019). Phylogenomics and morphological reconstruction of arcellinida testate amoebae highlight diversity of microbial eukaryotes in the neoproterozoic. Curr. Biol. 29, 991-1001.e3. doi: 10.1016/j.cub.2019.01.078

Lahr, D. J. G., Parfrey, L. W., Mitchell, E. A. D., Katz, L. A., and Lara, E. (2011). The chastity of amoebae: re-evaluating evidence for sex in amoeboid organisms. Proc. Biol. Sci. 278, 2081-2090. doi: 10.1098/rspb.2011.0289

Lamentowicz, Ł, Gąbka, M., Rusińska, A., Sobczyński, T., Owsianny, P. M., and Lamentowicz, M. (2011). Testate amoeba (Arcellinida, Euglyphida) ecology along a poor-rich gradient in fens of western Poland. Int. Rev. Hydrobiol. 96, 256-380.

Lamentowicz, Ł, Lamentowicz, M., and Gąbka, M. (2008). Testate amoebae ecology and local transfer function from a peatland in Western Poland. Wetlands 28, 164-175.

Lamentowicz, M., Balwierz, Z., Forysiak, J., Płóciennik, M., Kittel, P., Kloss, M., et al. (2009a). Multiproxy study of anthropogenic and climatic changes in the last two millennia from a small mire in central Poland. Hydrobiologia 631, 213-230. doi: 10.1007/s10750-009-9812-y

Lamentowicz, M., Bragazza, L., Buttler, A., Jassey, V. E. J., and Mitchell, E. A. D. (2013a). Seasonal patterns of testate amoeba diversity, community structure and species-environment relationships in four Sphagnum-dominated peatlands along a $1300 \mathrm{~m}$ altitudinal gradient in Switzerland. Soil Biol. Biochem. 67, $1-11$.

Lamentowicz, M., Gałka, M., Lamentowicz, Ł, Obremska, M., Kühl, N., Lücke, A., et al. (2015). Climate change over the last 4000 years in a Baltic bog in northern Poland revealed by a trait-based approach, biotic proxies, and stable isotopes. Palaeogeogr. Palaeoclimatol. Palaeoecol. 418, 261-277.

Lamentowicz, M., Gałka, M., Marcisz, K., Słowiński, M., Kajukało-Drygalska, K., Druguet Dayras, M., et al. (2019). Unveiling tipping points in longterm ecological records from Sphagnum-dominated peatlands. Biol. Lett. 15:20190043. doi: 10.1098/rsbl.2019.0043

Lamentowicz, M., Gałka, M., Milecka, K., Tobolski, K., Lamentowicz, L., Fiałkiewicz-Kozieł, B., et al. (2013b). A 1300-year multi-proxy, high-resolution record from a rich fen in northern Poland: reconstructing hydrology, land use and climate change. J. Quat. Sci. 28, 582-594.

Lamentowicz, M., Kajukało-Drygalska, K., Kołaczek, P., Jassey, V. E. J., Gąbka, M., and Karpińska-Kołaczek, M. (2020). Testate amoebae taxonomy and trait diversity are coupled along an openness and wetness gradient in pinedominated Baltic bogs. Eur. J. Protistol. 73:125674. doi: 10.1016/j.ejop.2020. 125674

Lamentowicz, M., Lamentowicz, Ł, van der Knaap, W. O., Gąbka, M., and Mitchell, E. A. D. (2010). Contrasting species-environment relationships in communities of testate amoebae, bryophytes and vascular plants along the fen-bog gradient. Microb. Ecol. 59, 499-510. doi: 10.1007/s00248-009-9617-6

Lamentowicz, M., Milecka, K., Gałka, M., Cedro, A., Pawlyta, J., Piotrowska, N. et al. (2009b). Climate and human induced hydrological change since AD 800 in an ombrotrophic mire in Pomerania (N Poland) tracked by testate amoebae, macro-fossilis, pollen tree-rings of pine. Boreas 38, 214-229.

Lamentowicz, M., and Mitchell, E. A. D. (2005). The ecology of testate amoebae (Protists) in Sphagnum in north-western Poland in relation to peatland ecology. Microb. Ecol. 50, 48-63.

Lamentowicz, M., Tobolski, K., and Mitchell, E. A. D. (2007). Palaeoecological evidence for anthropogenic acidification of a kettle-hole peatland in northern Poland. Holocene 17, 1185-1196.

Lansac-Tôha, F., Velho, L., Costa, D., Simões, N., and Alves, G. (2014). Structure of the testate amoebae community in different habitats in a neotropical floodplain. Braz. J. Biol. 74, 181-190.

Lara, E., Heger, T. J., Ekelund, F., Lamentowicz, M., and Mitchell, E. A. D. (2008). Ribosomal RNA genes challenge the monophyly of the Hyalospheniidae (Amoebozoa: Arcellinida). Protist 159, 165-176.

Laughlin, D. C. (2014). Applying trait-based models to achieve functional targets for theory-driven ecological restoration. Ecol. Lett. 17, 771-784. doi: 10.1111/ ele. 12288

Laureto, L. M. O., Cianciaruso, M. V., and Samia, D. S. M. (2015). Functional diversity: an overview of its history and applicability. Natureza Conserv. 13, 112-116. doi: 10.1016/j.ncon.2015.11.001 
Lavorel, S., and Garnier, E. (2002). Predicting changes in community composition and ecosystem functioning from plant traits: revisiting the Holy Grail. Funct. Ecol. 16, 545-556. doi: 10.1046/j.1365-2435.2002.00664.x

Lavorel, S., and Grigulis, K. (2012). How fundamental plant functional trait relationships scale-up to trade-offs and synergies in ecosystem services. J. Ecol. 100, 128-140.

Lawson, I. T., Jones, T. D., Kelly, T., Honorio Coronado, E. N., and Roucoux, K. H. (2014). The geochemistry of Amazonian peats. Wetlands 34, 905-915.

Lousier, J. D. (1974). Response of soil testacea to soil moisture fluctuations. Soil Biol. Biochem. 6, 235-239.

Lu, Y., Fritz, S. C., Stone, J. R., Krause, T. R., Whitlock, C., Brown, E. T., et al. (2017). Trends in catchment processes and lake evolution during the lateglacial and early- to mid-Holocene inferred from high-resolution XRF data in the Yellowstone region. J. Paleolimnol. 58, 551-569. doi: 10.1007/s10933-0179991-x

Luoto, T. P., and Ojala, A. E. K. (2018). Controls of climate, catchment erosion and biological production on long-term community and functional changes of chironomids in High Arctic lakes (Svalbard). Palaeogeogr. Palaeoclimatol. Palaeoecol. 505, 63-72. doi: 10.1016/j.palaeo.2018.05.026

Macumber, A. L., Blandenier, Q., Todorov, M., Duckert, C., Lara, E., Lahr, D. J. G., et al. (2020). Phylogenetic divergence within the Arcellinida (Amoebozoa) is congruent with test size and metabolism type. Eur. J. Protistol. 72:125645. doi: 10.1016/j.ejop.2019.125645

Macumber, A. L., Patterson, R. T., Roe, H. M., Reinhardt, E. G., Neville, L. A., and Swindles, G. T. (2014). Autoecological approaches to resolve subjective taxonomic divisions within arcellacea. Protist 165, 305-316. doi: 10.1016/j. protis.2014.03.004

Macumber, A. L., Roe, H., Prentice, S., Sayer, C., and Emson, D. (2017). “The use of geometric morphometrics to delimit functional traits in freshwater Arcellinida: the 'ECOTRAIT' Project," in 36th Annual Meeting of the German Society for Protozoology, (Meissen: German Society for Protozoology).

Marcisz, K., Colombaroli, D., Jassey, V. E. J., Tinner, W., Kołaczek, P., Gałka, M., et al. (2016). A novel testate amoebae trait-based approach to infer environmental disturbance in Sphagnum peatlands. Sci. Rep. 6:33907. doi: 10 . 1038/srep33907

Marcisz, K., Fournier, B., Gilbert, D., Lamentowicz, M., and Mitchell, E. A. D. (2014a). Response of Sphagnum peatland testate amoebae to a 1-year transplantation experiment along an artificial hydrological gradient. Microb. Ecol. 67, 810-818. doi: 10.1007/s00248-014-0367-8

Marcisz, K., Kołaczek, P., Gałka, M., Diaconou, A.-C., and Lamentowicz, M. (2020). Exceptional hydrological stability of a Sphagnum-dominated peatland over the Late Holocene. Quat. Sci. Rev. 231:106180. doi: 10.1016/j.quascirev.2020. 106180

Marcisz, K., Lamentowicz, Ł, Słowińska, S., Słowiński, M., Muszak, W., and Lamentowicz, M. (2014b). Seasonal changes in Sphagnum peatland testate amoeba communities along a hydrological gradient. Eur. J. Protistol. 50, 445455. doi: 10.1016/j.ejop.2014.07.001

Marcisz, K., Lamentowicz, M., Gałka, M., Colombaroli, D., Adolf, C., and Tinner, W. (2019). Responses of vegetation and testate amoeba trait composition to fire disturbances in and around a bog in central European lowlands (northern Poland). Quat. Sci. Rev. 208, 129-139. doi: 10.1016/j.quascirev.2019.02.003

Marcisz, K., Tinner, W., Colombaroli, D., Kołaczek, P., Słowiński, M., FiałkiewiczKozieł, B., et al. (2015). Long-term hydrological dynamics and fire history over the last 2000 years in CE Europe reconstructed from a high-resolution peat archive. Quat. Sci. Rev. 112, 138-152. doi: 10.1016/j.quascirev.2015.01.019

Mast, S. O., and Root, F. M. (1916). Observations on amoebae feeding on rotifers, nematodes and ciliates, and their bearing on the surface-tension theory. J. Exp. Zool. 21, 33-49.

Mattheeussen, R., Ledegancki, P., Vincke, S., Van de Vijver, B., Nijs, I., and Beyens, L. (2005). Habitat selection of aquatic testate amoebae communities on Qeqertarsuaq (Disko Island), West Greenland. Acta Protozool. 44:253.

Mazei, Y., and Tsyganov, A. N. (2006). Freshwater Testate Amoebae. Moscow: KMK.

McGill, B. J., Enquist, B. J., Weiher, E., and Westoby, M. (2006). Rebuilding community ecology from functional traits. Trends Ecol. Evol. 21, 178-185. doi: $10.1016 /$ j.tree.2006.02.002

McKeown, M. M., Wilmshurst, J. M., Duckert, C., Wood, J. R., and Mitchell, E. A. D. (2019). Assessing the ecological value of small testate amoebae
$(<45$ ? $\mu \mathrm{m})$ in New Zealand peatlands. Eur. J. Protistol. 68, 1-16. doi: 10.1016/j. ejop.2018.12.002

Medioli, F. S., and Scott, D. B. (1983). Holocene Arcellacea (Thécamoebians) from Eastern Canada. Washington, DC: Cushman Foundation for Foraminiferal Research.

Medioli, F. S., and Scott, D. B. (1988). Lacustrine thecamoebians (mainly Arcellaceans) as potential tools for palaeolimnological interpretations. Palaeogeogr. Palaeoclimatol. Palaeoecol. 62, 361-386. doi: 10.1016/00310182(88)90062-4

Medioli, F. S., Scott, D. B., and Abbott, B. H. (1987). A case study of protozoan intraclonal variability: taxonomic implications. J. Foraminif. Res. 17, $28-47$.

Medioli, F. S., Scott, D. B., Collins, E. S., and McCarthy, F. M. G. (1990). "Fossil thecamoebians: present status and prospects for the future," in Proceedings of the NATO Advanced Study Institute on paleoecology, biostratigraphy, paleoceanography and taxonomy of agglutinated foraminifera, eds C. Hemleben, M. A. Kaminski, W. Kuhnt, and D. B. Scott (Dordrecht: D. Reidel Publishing Company), 813-839.

Meisterfeld, R. (1991). Vertical distribution of Difflugia hydrostatica (Protozoa, Rhizopoda). Int. Vereinigung Theor. Angew. Limnol. Verhandlungen 24, $2726-$ 2728 .

Meisterfeld, R. (2002). "Order arcellinida kent," in An Illustrated Guide to the Protozoa. 2nd Edition, eds J. J. Lee, G. F. Leedale, and P. Bradbury (Lawrence: Allen Press Inc), 827-860.

Meyer, C., Desalme, D., Bernard, N., Binet, P., Toussaint, M.-L., and Gilbert, D. (2013). Using testate amoeba as potential biointegrators of atmospheric deposition of phenanthrene (polycyclic aromatic hydrocarbon) on "moss/soil interface-testate amoeba community" microecosystems. Ecotoxicology 22, 287294. doi: 10.1007/s10646-012-1025-x

Meyer, C., Gilbert, D., Gillet, F., Moskura, M., Franchi, M., and Bernard, N. (2012). Using "bryophytes and their associated testate amoeba" microsystems as indicators of atmospheric pollution. Ecol. Indic. 13, 144-151. doi: 10.1016/j. ecolind.2011.05.020

Mitchell, E. A. D., Buttler, A. J., Warner, B. G., and Gobat, J. M. (1999). Ecology of testate amoebae (Protozoa : Rhizopoda) in Sphagnum peatlands in the Jura mountains, Switzerland and France. Ecoscience 6, 565-576.

Mitchell, E. A. D., Charman, D. J., and Warner, B. G. (2008a). Testate amoebae analysis in ecological and paleoecological studies of wetlands: past, present and future. Biodiv. Conserv. 17, 2115-2137.

Mitchell, E. A. D., Lamentowicz, M., Payne, R. J., and Mazei, Y. (2014). Effect of taxonomic resolution on ecological and palaeoecological inference - a test using testate amoeba water table depth transfer functions. Quat. Sci. Rev. 91, 62-69. doi: 10.1016/j.quascirev.2014.03.006

Mitchell, E. A. D., Payne, R. J., and Lamentowicz, M. (2008b). Potential implications of differential preservation of testate amoebae shells for paleoenvironmental reconstruction in peatlands. J. Paleolimnol. 40, 603-618.

Mitchell, E. A. D., van der Knaap, W. O., van Leeuwen, J. F. N., Buttler, A., Warner, B. G., and Gobat, J. M. (2001). The palaeoecological history of the PrazRodet bog (Swiss Jura) based on pollen, plant macrofossils and testate amoebae (Protozoa). Holocene 11, 65-80.

Mulot, M., Marcisz, K., Grandgirard, L., Lara, E., Kosakyan, A., Robroek, B. J. M., et al. (2017). Genetic determinism vs. Phenotypic plasticity in protist morphology. J. Eukaryotic Microbiol. 64, 729-739. doi: 10.1111/jeu.12406

Naeem, S., and Wright, J. P. (2003). Disentangling biodiversity effects on ecosystem functioning: deriving solutions to a seemingly insurmountable problem. Ecol. Lett. 6, 567-579. doi: 10.1046/j.1461-0248.2003.00471.x

Nasser, N. A., Patterson, R. T., Galloway, J. M., and Falck, H. (2020a). Intralake response of Arcellinida (testate lobose amoebae) to gold mining-derived arsenic contamination in northern Canada: implications for environmental monitoring. PeerJ 8:e9054. doi: 10.7717/peerj.9054

Nasser, N. A., Patterson, R. T., Roe, H. M., Galloway, J. M., Falck, H., Palmer, M. J., et al. (2016). Lacustrine Arcellinina (Testate Amoebae) as bioindicators of arsenic contamination. Microb. Ecol. 72, 130-149. doi: 10.1007/s00248-0160752-6

Nasser, N. A., Patterson, R. T., Roe, H. M., Galloway, J. M., Falck, H., and Sanei, H. (2020b). Use of Arcellinida (testate lobose amoebae) arsenic tolerance limits as a novel tool for biomonitoring arsenic contamination in lakes. Ecol. Indic. 113:106177. doi: 10.1016/j.ecolind.2020.106177 
Neville, L. A., McCarthy, F. M., and MacKinnon, M. D. (2010). Seasonal environmental and chemical impact on thecamoebian community composition in an oil sands reclamation wetland in Northern Alberta. Palaeontol. Electron. $13,1-14$.

Neville, L. A., McCarthy, F. M. G., MacKinnon, M. D., Swindles, G. T., and Marlowe, P. (2011). Thecamoebians (Testate amoebae) as proxies of ecosystem health and reclamation success in constructed wetlands in the oil sands of Alberta, Canada. J. Foraminif. Res. 41, 230-247. doi: 10.2113/gsjfr.41.3.230

Neville, L. A., Patterson, R. T., Gammon, P., and Macumber, A. L. (2014) Relationship between ecological indicators (Arcellacea), total mercury concentrations and grain size in lakes within the Athabasca oil sands region, Alberta. Environ. Earth Sci. 72, 577-588. doi: 10.1007/s12665-013-2979-6

Nguyen-Viet, H., Gilbert, D., Bernard, N., Mitchell, E. A. D., and Badot, P.M. (2004). Relationship between atmospheric pollution characterized by NO2 concentrations and testate amoebae abundance and diversity. Acta Protozool. $43,233-239$.

Noble, I. R., and Slatyer, R. O. (1980). The use of vital attributes to predict successional changes in plant communities subject to recurrent disturbances. Vegetatio 43, 5-21. doi: 10.1007/BF00121013

Nock, C. A., Vogt, R. J., and Beisner, B. E. (2016). Functional Traits. eLS. Chichester: John Wiley \& Sons, Ltd, doi: 10.1002/9780470015902.a0026282

Ogden, C. G. (1991). Gas vacuoles and flotation in the testate amoeba Arcella discoides. J. Protozool. 38, 269-270. doi: 10.1111/j.1550-7408.1991.tb0 4441.x

Ogden, C. G., and Hedley, R. H. (1980). An Atlas of Freshwater Testate Amoebae. London: Oxford University Press.

Ooms, M., Beyens, L., and Temmerman, S. (2011). Testate amoebae as estuarine water-level indicators: modern distribution and the development of a transfer function from a freshwater tidal marsh (Scheldt estuary, Belgium). J. Quat. Sci. 26, 819-828. doi: 10.1002/jqs.1510

Opravilova, V., and Hajek, M. (2006). The variation of testacean assemblages (Rhizopoda) along the complete base-richness gradient in fens: a case study from the Western Carpathians. Acta Protozool. 45, 191-204.

Page, S. E., and Baird, A. J. (2016). Peatlands and global change: response and resilience. Annu. Rev. Environ. Resour. 41, 35-57. doi: 10.1146/annurevenviron-110615-085520

Patterson, R. T. (1996). Arcellaceans (Thecamoebians) as proxies of arsenic and mercury contamination in northeastern Ontario lakes. J. Foraminif. Res. 26, 172-183. doi: 10.2113 /gsjfr.26.2.172

Patterson, R. T., Huckerby, G., Kelly, T. J., Swindles, G. T., and Nasser, N. A. (2015). Hydroecology of Amazonian lacustrine Arcellinida (testate amoebae): a case study from Lake Quistococha, Peru. Eur. J. Protistol. 51, 460-469. doi: 10.1016/j.ejop.2015.06.009

Patterson, R. T., and Kumar, A. (2002). A review of current testate rhizopod (thecamoebian) research in Canada. Palaeogeogr. Palaeoclimatol. Palaeoecol. 180, 225-251. doi: 10.1016/S0031-0182(01)00430-8

Patterson, R. T., Lamoureux, E. D. R., Neville, L. A., and Macumber, A. L. (2013). Arcellacea (Testate Lobose Amoebae) as $\mathrm{pH}$ indicators in a pyrite mineacidified Lake, Northeastern Ontario, Canada. Microb. Ecol. 65, 541-554. doi: 10.1007/s00248-012-0108-9

Patterson, R. T., MacKinnon, K. D., Scott, D. B., and Medioli, F. S. (1985). Arcellaceans ("Thécamoebians") in small lakes of new Brunswick and Nova Scottia: modern distribution and holocene stratigraphic changes. J. Foraminif. Res. 15, 114-137. doi: 10.2113/gsjfr.15.2.114

Patterson, R. T., Roe, H. M., and Swindles, G. T. (2012). Development of an Arcellacea (testate lobose amoebae) based transfer function for sedimentary phosphorus in lakes. Palaeogeogr. Palaeoclimatol. Palaeoecol. 34, 32-44. doi: 10.1016/j.palaeo.2012.05.028

Payne, R., and Mitchell, E. A. D. (2007). Ecology of testate amoebae from mires in the central rhodope mountains, greece and development of a transfer function for palaeohydrological reconstruction. Protist 158, 159-171. doi: 10.1016/j. protis.2006.11.003

Payne, R. J., Creevy, A., Malysheva, E., Ratcliffe, J., Andersen, R., Tsyganov, A. N., et al. (2016). Tree encroachment may lead to functionally-significant changes in peatland testate amoeba communities. Soil Biol. Biochem. 98, 18-21. doi: 10.1016/j.soilbio.2016.04.002

Payne, R. J., Lamentowicz, M., and Mitchell, E. A. D. (2011). The perils of taxonomic inconsistency in quantitative palaeoecology: experiments with testate amoeba data. Boreas 40, 15-27. doi: 10.1111/j.1502-3885.2010. 00174.x

Penard, E. (1902). Faune Rhizopodique du Bassin du Leman. Polson, MT: Henry Kundig. doi: 10.5962/bhl.title.1711

Peppe, D. J., Baumgartner, A., Flynn, A., and Blonder, B. (2018). “Reconstructing paleoclimate and paleoecology using fossil leaves," in Methods in Paleoecology: Reconstructing Cenozoic Terrestrial Environments and Ecological Communities, eds D. A. Croft, D. F. Su, and S. W. Simpson (Cham: Springer International Publishing), 289-317. doi: 10.1007/978-3-319-94265-0_13

Pérez-Juárez, H., Serrano-Vázquez, A., Kosakyan, A., Mitchell, E. A. D., Rivera Aguilar, V. M., Lahr, D. J. G., et al. (2017). Quadrulella texcalense sp. nov. from a Mexican desert: an unexpected new environment for hyalospheniid testate amoebae. Eur. J. Protistol. 61, 253-264. doi: 10.1016/j.ejop.2017.06.008

Porter, S. (2011). The rise of predators. Geology 39, 607-608. doi: 10.1130/ focus 062011.1

Porter, S. M., and Knoll, A. H. (2000). Testate amoebae in the Neoproterozoic Era: evidence from vase- shaped microfossils in the Chuar Group, Grand Canyon. Paleobiology 26, 360-385. doi: 10.1666/0094-8373(2000)026<0360:TAITNE $>2$. $0 . \mathrm{CO} ; 2$

Porter, S. M., Meisterfeld, R., and Knoll, A. H. (2003). Vase-shaped microfossils from the neoproterozoic chuar group, Grand Canyon: a classification guided by Modern Testate Amoebae. J. Paleont. 77, 409-429. doi: 10.1666/00223360(2003)077<0409:VMFTNC>2.0.CO;2

Porto, A., Shirai, L. T., de Oliveira, F. B., and Marroig, G. (2013). Size variation, growth strategies, and the evolution of modularity in the mammalian skull. Evolution 67, 3305-3322. doi: 10.1111/evo.12177

Pratt, J. R., and Cairns, J. Jr. (1985). Functional groups in the protozoa: roles in differing ecosystems1,2. J. Protozool. 32, 415-423. doi: 10.1111/j.1550-7408. 1985.tb04037.x

Prentice, S. V. (2019). Tracking Eutrophication in UK Lakes: The Potential of Testate Amoebae. Ph. D. Thesis, Queen's University Belfast, Belfast.

Prentice, S. V., Roe, H. M., Bennion, H., Sayer, C. D., and Salgado, J. (2018). Refining the palaeoecology of lacustrine testate amoebae: insights from a plant macrofossil record from a eutrophic Scottish lake. J. Paleolimnol. 60, 189-207. doi: 10.1007/s10933-017-9966-y

Puppe, D. (2020). Review on protozoic silica and its role in silicon cycling. Geoderma 365:114224. doi: 10.1016/j.geoderma.2020.114224

Qin, Y. M., Payne, R. J., Gu, Y. S., Huang, X. Y., and Wang, H. M. (2012). Ecology of testate amoebae in Dajiuhu peatland of Shennongjia Mountains, China, in relation to hydrology. Front. Earth Sci. 6:57-65. doi: 10.1007/s11707-0120307-1

R Development Core Team (2020). R: A Language and Environment for Statistical Computing. Vienna: R Foundation for Statistical Computing.

Raikov, I. B., Karadzhan, B. P., Kaur, R., and Mignot, J. P. (1989). Nuclear finestructure at interphase and during encystment in 2 forms of the testacean Arcella-Vulgaris. Eur. J. Protistol. 24, 369-380.

Ratcliffe, J. L., Creevy, A., Andersen, R., Zarov, E., Gaffney, P. P. J., Taggart, M. A., et al. (2017). Ecological and environmental transition across the forested-toopen bog ecotone in a west Siberian peatland. Sci. Total Environ. 607, 816-828. doi: 10.1016/j.scitotenv.2017.06.276

Raunkiaer, C. (1934). The Life Forms of Plants and Statistical Plant Geography; Being the Collected Papers of C. Oxford: Oxford University Publishing.

Reinhardt, E. G., Dalby, A. P., Kumar, A., and Patterson, T. R. (1998). Arcellaccans as pollution indicators in mine tailing contaminated lakes near Cobalt, Ontario, Canada. Micropaleontology 44, 131-148. doi: 10.2307/1486066

Reinhardt, E. G., Little, M., Donato, S., Findlay, D., Krueger, A., Clark, C., et al. (2005). Arcellacean (thecamoebian) evidence of land-use change and eutrophication in Frenchman's Bay, Pickering, Ontario. Environ. Geol. 47, 729-739. doi: 10.1007/s00254-004-1213-y

Riveiros, N. V., Babalola, A. O., Boudreau, R. E. A., Patterson, R. T., Roe, H. M., and Doherty, C. (2007). Modern distribution of salt marsh foraminifera and thecamoebians in the Seymour-Belize Inlet Complex, British Columbia, Canada. Mar. Geol. 242, 39-63. doi: 10.1016/j.margeo.2006. 08.009

Roberts, N. (2013). The Holocene: An Environmental History, 3rd Edn. Hoboken, NJ: Wiley-Blackwell.

Robleńo, I., Storkey, J., Solé-Senan, X. O., and Recasens, J. (2018). Using the response-effect trait framework to quantify the value of fallow patches in 
agricultural landscapes to pollinators. Appl. Veg. Sci. 21, 267-277. doi: 10.1111/ avsc. 12359

Robroek, B. J. M., Jassey, V. E. J., Payne, R. J., Martí, M., Bragazza, L., Bleeker, A., et al. (2017). Taxonomic and functional turnover are decoupled in European peat bogs. Nat. Commun. 8:1161. doi: 10.1038/s41467-01701350-5

Robson, T. M., Pancotto, V. A., Scopel, A. L., Flint, S. D., and Caldwell, M. M. (2005). Solar UV-B influences microfaunal community composition in a Tierra del Fuego peatland. Soil Biol. Biochem. 37, 2205-2215. doi: 10.1016/j.soilbio. 2005.04.002

Roe, H. M., Charman, D. J., and Gehrels, W. R. (2002). Fossil testate amoebae in costal deposits in the UK: implications for studies of sea-level change. J. Quat. Sci. 17, 411-429. doi: 10.1002/jqs.704

Roe, H. M., and Patterson, R. T. (2006). Distribution of thecamoebians (testate amoebae) in small lakes and ponds, Barbados, West Indies. J. Foraminif. Res. 36, 116-134. doi: 10.2113/36.2.116

Roe, H. M., and Patterson, R. T. (2014). Arcellacea (Testate Amoebae) as bioindicators of road salt contamination in lakes. Microb. Ecol. 68, 299-313. doi: 10.1007/s00248-014-0408-3

Roe, H. M., Patterson, R. T., and Swindles, G. T. (2010). Controls on the contemporary distribution of lake thecamoebians (testate amoebae) within the Greater Toronto Area and their potential as water quality indicators. J. Paleolimnol. 43, 955-975. doi: 10.1007/s10933-009-9380-1

Root, R. B. (1967). The niche exploitation pattern of the blue-gray gnatcatcher. Ecol. Monogr. 37, 317-350. doi: 10.2307/1942327

Rull, V. (2010). Ecology and palaeoecology: two approaches, one objective. Open Ecol. J. 3, 1-5. doi: 10.2174/1874213001003020001

Rydin, H., and Jeglum, J. K. (2006). The Biology of Peatlands. Oxford: Oxford University Press. doi: 10.1093/acprof:oso/9780198528722.001.0001

Salgado, J., Sayer, C., Carvalho, L., Davidson, T., and Gunn, I. (2010). Assessing aquatic macrophyte community change through the integration of palaeolimnological and historical data at Loch Leven, Scotland. J. Paleolimnol. 43:191. doi: 10.1007/s10933-009-9389-5

Sandon, H. (1927). The Composition and Distribution of the Protozoan Fauna of the Soil. Biological Monographs and Manuals. Edinburgh: Oliver and Boyd. doi: 10.1097/00010694-192705000-00009

Schimper, A. F. W. (1903). Plant-Geography Upon a Physiological Basis. Oxford: Clarendon Press. doi: 10.5962/bhl.title.122577

Schlegel, M., and Meisterfeld, R. (2003). The species problem in protozoa revisited. Eur. J. Protistol. 39, 349-355. doi: 10.1078/S0932-4739(04)70109-1

Schmidt, A. R., Girard, V., Perrichot, V., and Schönborn, W. (2010). Testate Amoebae from a cretaceous forest floor microbiocoenosis of France. J. Eukaryotic Microbiol. 57, 245-248. doi: 10.1111/j.1550-7408.2010.00471.x

Schmidt, A. R., Ragazzi, E., Coppellotti, O., and Roghi, G. (2006). A microworld in Triassic amber. Nature 444, 835-835. doi: 10.1038/444835a

Schönborn, W. (1962). Über Planktismus und Zyklomorphose bei Difflugia limnetica (LEVANDER) PENARD. Limnologica (Berlin) 1, 21-34.

Schönborn, W. (1965). Untersuchungen über die Zoochlorellen-Symbiose der Hochmoor-Testaceen. Limnologica 3, 173-176.

Schönborn, W. (1989). The topophenetic analysis as a method to elucidate the phylogeny of testate Amoebae (Protozoa, Testacealobosia and Testaceafilosia). Arch. Protisten. 137, 223-245. doi: 10.1016/S0003-9365(89)80029-6

Schönborn, W., Dorfelt, H., Foissner, W., Krienitz, L., and Schafer, U. (1999). A fossilized microcenosis in Triassic amber. J. Eukaryotic Microbiol. 46, 571-584. doi: 10.1111/j.1550-7408.1999.tb05133.x

Schönborn, W., Petz, W., Wanner, M., and Foissner, W. (1987). Observations on the morphology and ecology of the soil-inhabiting testate amoebae Schoenbornia humicola (SCHÖNBORN, 1964) DECLOITRE, 1964 (Protozoa, Rhizopoda). Arch. Protisten. 134, 315-330. doi: 10.1016/S0003-9365(87)8 0004-0

Schröter, D., Wolters, V., and De Ruiter, P. C. (2003). C and N mineralisation in the decomposer food webs of a European forest transect. Oikos 102, 294-308. doi: $10.1034 / j .1600-0579.2003 .12064 . x$

Schulz, G., Maraun, M., Völcker, E., Scheu, S., and Krashevska, V. (2018). Evaluation of morphological characteristics to delineate taxa of the genus Trigonopyxis (Amoebozoa, Arcellinida). Protist 169, 190-205. doi: 10.1016/j. protis.2018.02.005
Schwind, L. T. F., Arrieira, R. L., Bonecker, C. C., and Lansac-Töha, F. A. (2016a). Chlorophyll-a and suspended inorganic material affecting the shell traits of testate amoebae community. Acta Protozool. 55, 145-154. doi: 10.4467/ 16890027AP.16.014.5746

Schwind, L. T. F., Leite Arrieira, R., Mantovano, T., Costa Bonecker, C., and Lansac-Tôha, F. A. (2016b). Temporal influence on the functional traits of testate amoebae in a floodplain lake. Limnetica 35, 355-364. doi: 10.23818/limn. 35.28

Schwörer, C., Kaltenrieder, P., Glur, L., Berlinger, M., Elbert, J., Frei, S., et al. (2014). Holocene climate, fire and vegetation dynamics at the treeline in the Northwestern Swiss Alps. Veg. Hist. Archaeobot. 23, 479-496. doi: 10.1007/ s00334-013-0411-5

Searles, P. S., Kropp, B. R., Flint, S. D., and Caldwell, M. M. (2001). Influence of solar UV-B radiation on peatland microbial communities of southern Argentinia. New Phytol. 152, 213-221.

Shipley, B., De Bello, F., Cornelissen, J. H. C., Laliberté, E., Laughlin, D. C., and Reich, P. B. (2016). Reinforcing loose foundation stones in traitbased plant ecology. Oecologia 180, 923-931. doi: 10.1007/s00442-0163549-x

Siemensma, F. J. (2019). Microworld, World of Amoeboid Organisms. Kortenhoef: World-wide electronic publication.

Sillasoo, Ü, Mauquoy, D., Blundell, A., Charman, D., Blaauw, M., Daniell, J. R. G., et al. (2007). Peat multi-proxy data from Männikjärve bog as indicators of late Holocene climate changes in Estonia. Boreas 36, 20-37.

Singer, D., Kosakyan, A., Pilonnel, A., Mitchell, E. A. D., and Lara, E. (2015). Eight species in the Nebela collaris complex: Nebela gimlii (Arcellinida, Hyalospheniidae), a new species described from a Swiss raised bog. Eur. J. Protistol. 51, 79-85. doi: 10.1016/j.ejop.2014.11.004

Singer, D., Kosakyan, A., Seppey, C. V. W., Pillonel, A., Fernández, L. D., Fontaneto, D., et al. (2018). Environmental filtering and phylogenetic clustering correlate with the distribution patterns of cryptic protist species. Ecology 99, 904-914. doi: 10.1002/ecy.2161

Singer, D., Mitchell, E. A. D., Payne, R. J., Blandenier, Q., Duckert, C., Fernández, L. D., et al. (2019). Dispersal limitations and historical factors determine the biogeography of specialized terrestrial protists. Mol. Ecol. 28, 3089-3100. doi: 10.1111/mec.15117

Steele, R. E., Nasser, N. A., Patterson, R. T., Gregory, B. R. B., Roe, H. M., and Reinhardt, E. G. (2018). An assessment of sub-meter scale spatial variability of arcellinida (Testate Lobose Amoebae) assemblages in a temperate lake: implications for limnological studies. Microb. Ecol. 76, 680-694. doi: 10.1007/ s00248-018-1157-5

Steele, R. E., Patterson, R. T., Hamilton, P. B., Nasser, N. A., and Roe, H. M. (2020). Assessment of FlowCam technology as a potential tool for rapid semi-automatic analysis of lacustrine Arcellinida (testate lobose amoebae). Environ. Technol. Innov. 17:100580. doi: 10.1016/j.eti.2019.100580

Stump, A. B. (1935). Observations on the feeding of Difflugia, Pontigulasia and Lesquereusia. Biol. Bull. Woods Hole 69, 136-142.

Suding, K. N., Lavorel, S., Chapin, F. S. III, Cornelissen, J. H. C., Díaz, S., Garnier, E., et al. (2008). Scaling environmental change through the community-level: a trait-based response-and-effect framework for plants. Glob. Change Biol. 14, 1125-1140. doi: 10.1111/j.1365-2486.2008.01557.x

Sullivan, M. E., and Booth, R. K. (2011). The potential influence of short-term environmental variability on the composition of testate amoeba communities in sphagnum peatlands. Microb. Ecol. 62, 80-93. doi: 10.1007/s00248-011-9875-y

Swindles, G. T., Baird, A. J., Kilbride, E., Low, R., and Lopez, O. (2018). Testing the relationship between testate amoeba community composition and environmental variables in a coastal tropical peatland. Ecol. Indic. 91, 636-644. doi: 10.1016/j.ecolind.2018.03.021

Swindles, G. T., Lamentowicz, M., Reczuga, M., and Galloway, J. M. (2016). Palaeoecology of testate amoebae in a tropical peatland. Eur. J. Protiston. 55, 181-189. doi: 10.1016/j.ejop.2015.10.002

Swindles, G. T., Reczuga, M., Lamentowicz, M., Raby, C. L., Turner, T. E., Charman, D., et al. (2014). Ecology of testate amoebae in an Amazonian Peatland and development of a transfer function for palaeohydrological reconstruction. Microb. Ecol. 68, 284-298.

Todorov, M., Golemansky, V., Mitchell, E. A. D., and Heger, T. J. (2009). Morphology, biometry, and taxonomy of freshwater and marine 
interstitial cyphoderia (Cercozoa: Euglyphida). J. Eukaryot. Microbiol. 56, 279-289.

Tolonen, K., Warner, B. G., and Vasander, H. (1992). Ecology of testaceans (Protozoa, Rhizopoda) in mires in Southern Finland .1. Autecology. Arch. Protisten. 142, 119-138.

Tolonen, K., Warner, B. G., and Vasander, H. (1994). Ecology of testaceans (Protozoa, Rhizopoda) in mires in Southern Finland .2. Multivariate-analysis. Arch. Protisten. 144, 97-112.

Tsyganov, A. N., Keuper, F., Aerts, R., and Beyens, L. (2013). Flourish or flush: effects of simulated extreme rainfall events on sphagnum-dwelling testate amoebae in a subarctic bog (Abisko, Sweden). Microb. Ecol. 65, 101-110. doi: 10.1007/s00248-012-0115-X

University of Leeds Peat Club, Bacon, K. L., Baird, A. J., Blundell, A., Bourgault, M.A., Chapman, P. J., et al. (2017). Questioning ten common assumptions about peatlands. Mires Peat 19, 1-23. doi: 10.19189/MaP.2016.OMB.253

van Bellen, S., Magnan, G., Davies, L., Froese, D., Mullan-Boudreau, G., Zaccone, C., et al. (2018). Testate amoeba records indicate regional 20th-century lowering of water tables in ombrotrophic peatlands in central-northern Alberta, Canada. Glob. Change Biol. 24, 2758-2774. doi: 10.1111/gcb.14143

van Bellen, S., Mauquoy, D., Payne, R. J., Roland, T. P., Daley, T. J., Hughes, P. D. M., et al. (2014). Testate amoebae as a proxy for reconstructing Holocene water table dynamics in southern Patagonian peat bogs. J. Quat. Sci. 29, 463-474. doi: 10.1002/jqs.2719

van Bellen, S., Mauquoy, D., Payne, R. J., Roland, T. P., Hughes, P. D. M., Daley, T. J., et al. (2017). An alternative approach to transfer functions? Testing the performance of a functional trait-based model for testate amoebae. Palaeogeogr. Palaeoclimatol. Palaeoecol. 468, 173-183. doi: 10.1016/j.palaeo.2016.12.005

van der Sande, M. T., Gosling, W., Correa-Metrio, A., Prado-Junior, J., Poorter, L., Oliveira, R. S., et al. (2019). A 7000-year history of changing plant trait composition in an Amazonian landscape; the role of humans and climate. Ecol. Lett. 22, 925-935. doi: 10.1111/ele.13251

Velho, L. F. M., Lansac-Tôha, F. A., and Bini, L. M. (2003). Influence of environmental heterogeneity on the structure of testate amoebae (Protozoa, Rhizopoda) assemblages in the plankton of the Upper Paraná River Floodplain, Brazil. Int. Rev. Hydrobiol. 88, 154-166. doi: 10.1002/iroh.200390011

Violle, C., Navas, M.-L., Vile, D., Kazakou, E., Fortunel, C., Hummel, I., et al. (2007). Let the concept of trait be functional! Oikos 116, 882-892. doi: 10.1111/ j.0030-1299.2007.15559.x

Walker, I. R., and Cwynar, L. C. (2006). Midges and palaeotemperature reconstruction-the North American experience. Quat. Sci. Rev. 25, 1911-1925. doi: 10.1016/j.quascirev.2006.01.014

Wall, A. A. J., Gilbert, D., Magny, M., and Mitchell, E. A. D. (2010a). Testate amoeba analysis of lake sediments: impact of filter size and total count on estimates of density, species richness and assemblage structure. J. Paleolimnol. 43, 689-704. doi: 10.1007s/s10933-009-9360-5

Wall, A. A. J., Magny, M., Mitchell, E. A. D., Vannière, B., and Gilbert, D. (2010b). Response of testate amoeba assemblages to environmental and climatic changes during the Lateglacial-Holocene transition at Lake Lautrey (Jura Mountains, eastern France). J. Quat. Sci. 25, 945-956. doi: 10.1002/jqs.1377

Wanner, M. (1994). Effects of light, temperature, fertilizers and pesticides on shell size of the common freshwater and soil species Cyclopyxis kahli (Rhizopoda, Testacealobosia). Limnologica 24, 333-338.

Wanner, M. (1999). A review on the variability of testate amoebae: methodological approaches, environmental influences and taxonomical implications. Acta Protozool. 38, 15-29.

Wanner, M., and Meisterfeld, R. (1994). Effects of some environmental-factors on the shell morphology of testate amebas (Rhizopoda, Protozoa). Eur. J. Protistol. 30, 191-195. doi: 10.1016/S0932-4739(11)80029-5

Wanner, M., Seidl-Lampa, B., Höhn, A., Puppe, D., Meisterfeld, R., and Sommer, M. (2016). Culture growth of testate amoebae under different silicon concentrations. Eur. J. Protistol. 56, 171-179. doi: 10.1016/j.ejop.2016. 08.008

Wanner, M., and Xylander, W. E. R. (2005). Biodiversity development of terrestrial testate amoebae: is there any succession at all? Biol. Fertil. Soils 41, 428-438. doi: 10.1007/s00374-005-0850-y
Warner, B. G. (1987). Abundance and diversity of testate amoebae (Rhizopoda, Testacea) in Sphagnum peatlands in south-western Ontario, Canada. Arch. Protisten. 133, 173-189. doi: 10.1016/S0003-9365(87)80051-9

Warner, B. G., and Chmielewski, J. G. (1992). Testate Amoebae (Protozoa) as indicators of drainage in a forested mire, Northern Ontario, Canada. Arch. Protistenkd. 141, 179-183. doi: 10.1016/S0003-9365(11)80067-9

Warner, B. G., Kubiw, H. J., and Hanf, K. I. (1989). An anthropogenic cause for quaking mire formation in southwestern Ontario. Nature 340, 380-384. doi: 10.1038/340380a0

Watchorn, M. A., Hamilton, P. B., and Patterson, R. T. (2013). The paleolimnology of Haynes Lake, Oak Ridges Moraine, Ontario, Canada: documenting anthropogenic and climatic disturbances. Environ. Earth Sci. 68, 1823-1834. doi: $10.1007 / \mathrm{s} 12665-012-1870-1$

Weiher, E., van der Werf, A., Thompson, K., Roderick, M., Garnier, E., and Eriksson, O. (1999). Challenging Theophrastus: a common core list of plant traits for functional ecology. J. Veg. Sci. 10, 609-620. doi: 10.2307/32 37076

Wiik, E., Bennion, H., Sayer, C., Davidson, T., Clarke, S., McGowan, S., et al. (2015). The coming and going of a marl lake: multi-indicator palaeolimnology reveals abrupt ecological change and alternative views of reference conditions. Front. Ecol. Evol. 3:82. doi: 10.3389/fevo.2015.00082

Wilkinson, D. A., and Mitchell, E. A. D. (2010). Testate amoebae and nutrient cycling with particular reference to soils. Geomicrobiol. J. 27, 520-533. doi: 10.1080/01490451003702925

Willis, K. J., and MacDonald, G. M. (2011). Long-term ecological records and their relevance to climate change predictions for a warmer world. Annu. Rev. Ecol. Evol. Syst. 42, 267-287. doi: 10.1146/annurev-ecolsys-102209-144704

Wilmshurst, J. M., Wiser, S. K., and Charman, D. J. (2003). Reconstructing Holocene water tables in New Zealand using testate amoebae: differential preservation of tests and implications for the use of transfer functions. Holocene 13, 61-72. doi: 10.1191/0959683603hl595rp

Woodland, W. A., Charman, D. J., and Sims, C. (1998). Quantitative estimates of water tables and soil moisture in holocene peatlands from testate amoebae. Holocene 8, 261-273. doi: 10.1191/095968398667004497

Wright, I. J., Reich, P. B., Westoby, M., Ackerly, D. D., Baruch, Z., Bongers, F., et al. (2004). The worldwide leaf economics spectrum. Nature 428, 821-827. doi: $10.1038 /$ nature 02403

Yeates, G. W., and Foissner, W. (1995). Testate amoebae as predators of nematodes. Biol. Fertil. Soils 20, 1-7. doi: 10.1007/bf00307834

Yu, Z., Zhang, W., Liu, L., and Yang, J. (2014). Evidence for two different morphotypes of Difflugia tuberspinifera from China. Eur. J. Protistol. 50, 205-211. doi: 10.1016/j.ejop.2013.12.003

Zelditch, M. L., Swiderski, D. L., and Sheets, H. D. (2012). Geometric Morphometrics for Biologists: A Primer. Hoboken, NY: Academic Press.

Zhang, H., Amesbury, M. J., Piilo, S. R., Garneau, M., Gallego-Sala, A., and Väliranta, M. M. (2020a). Recent changes in peatland testate amoeba functional traits and hydrology within a replicated site network in Northwestern Québec, Canada. Front. Ecol. Evol. 8:228. doi: 10.3389/fevo.2020.00228

Zhang, H., Väliranta, M., Piilo, S., Amesbury, M. J., Aquino-López, M. A., Roland, T. P., et al. (2020b). Decreased carbon accumulation feedback driven by climateinduced drying of two southern boreal bogs over recent centuries. Glob. Change Biol. 26, 2435-2448. doi: 10.1111/gcb.15005

Conflict of Interest: The authors declare that the research was conducted in the absence of any commercial or financial relationships that could be construed as a potential conflict of interest.

Copyright (c) 2020 Marcisz, Jassey, Kosakyan, Krashevska, Lahr, Lara, Lamentowicz, Lamentowicz, Macumber, Mazei, Mitchell, Nasser, Patterson, Roe, Singer, Tsyganov and Fournier. This is an open-access article distributed under the terms of the Creative Commons Attribution License (CC BY). The use, distribution or reproduction in other forums is permitted, provided the original author(s) and the copyright owner(s) are credited and that the original publication in this journal is cited, in accordance with accepted academic practice. No use, distribution or reproduction is permitted which does not comply with these terms. 